\title{
Economic Impact of Permitting Timelines on Geothermal Power in California, Nevada, and Utah
}

Ghanashyam Neupane and Birendra Adhikari

Idaho National Laboratory

January 2022

The INL is a U.S. Department of Energy National Laboratory operated by Battelle Energy Alliance 


\section{DISCLAIMER}

This information was prepared as an account of work sponsored by an agency of the U.S. Government. Neither the U.S. Government nor any agency thereof, nor any of their employees, makes any warranty, expressed or implied, or assumes any legal liability or responsibility for the accuracy, completeness, or usefulness, of any information, apparatus, product, or process disclosed, or represents that its use would not infringe privately owned rights. References herein to any specific commercial product, process, or service by trade name, trade mark, manufacturer, or otherwise, does not necessarily constitute or imply its endorsement, recommendation, or favoring by the U.S. Government or any agency thereof. The views and opinions of authors expressed herein do not necessarily state or reflect those of the U.S. Government or any agency thereof. 


\title{
Economic Impact of Permitting Timelines on Geothermal Power in California, Nevada, and Utah
}

\author{
Ghanashyam Neupane and Birendra Adhikari \\ Idaho National Laboratory
}

January, 2022

\begin{abstract}
Idaho National Laboratory
Idaho Falls, Idaho 83415
\end{abstract}

http://www.inl.gov

Prepared for the

U.S. Department of Energy

Geothermal Technologies Office

Under DOE Idaho Operations Office

Contract DE-AC07-05ID14517 


\section{Table of Contents}

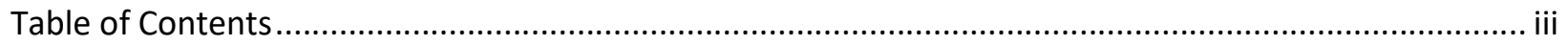

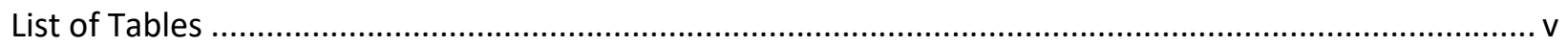

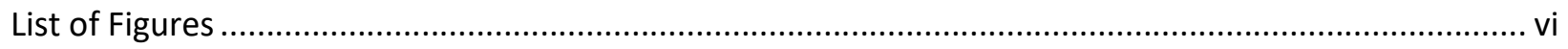

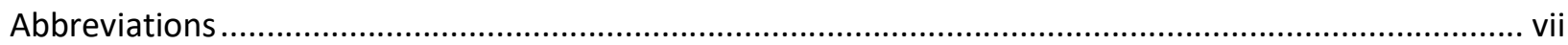

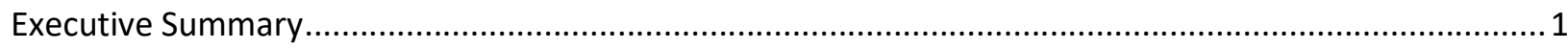

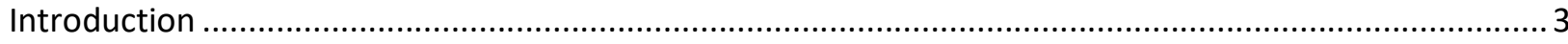

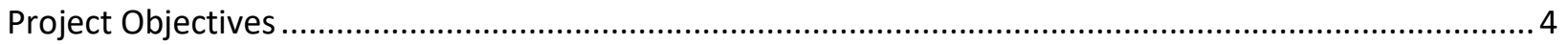

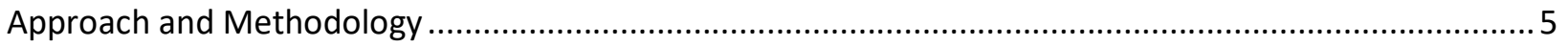

Permitting Data

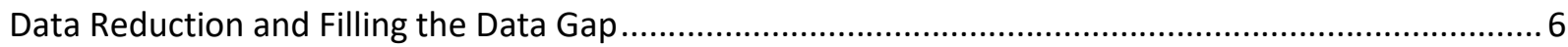

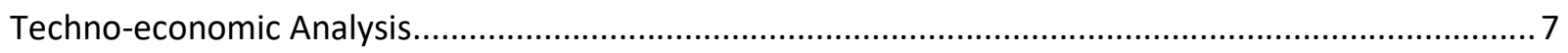

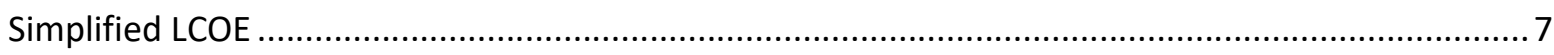

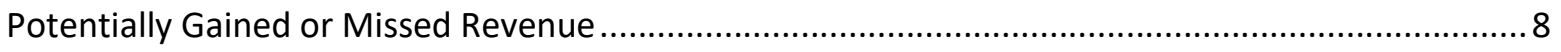

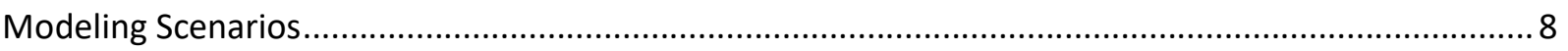

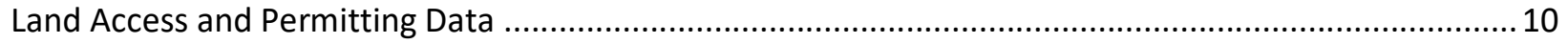

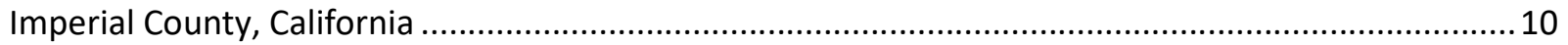

Permitting and Reviewing Agencies for Imperial County Projects ...............................................10

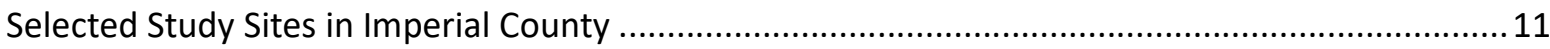

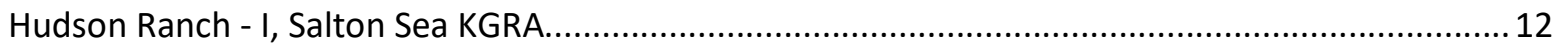

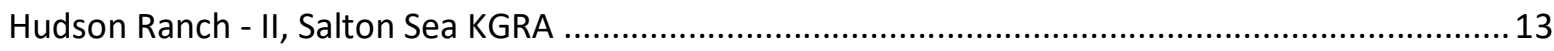

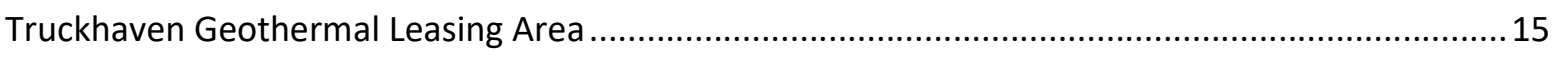

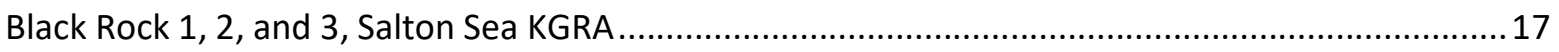

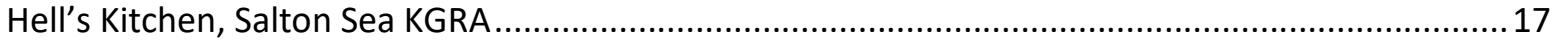

Selected Study Sites in Churchill County, Nevada .......................................................................... 18

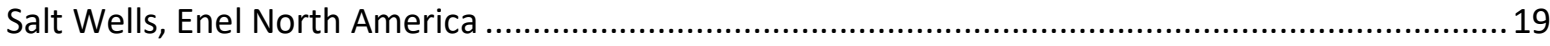

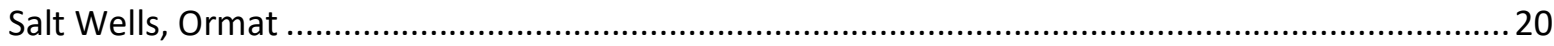

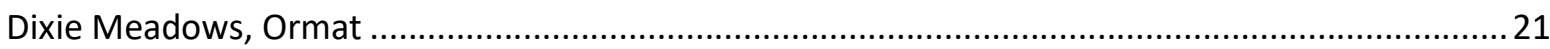

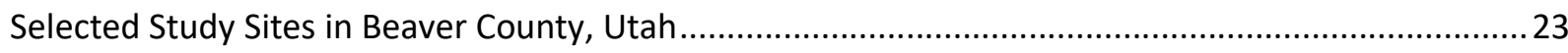

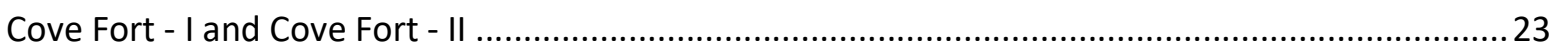

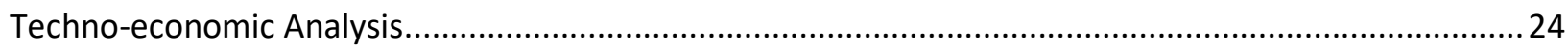

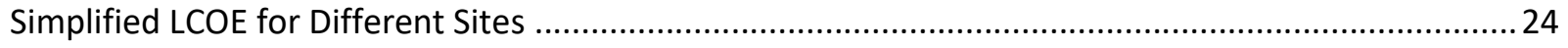

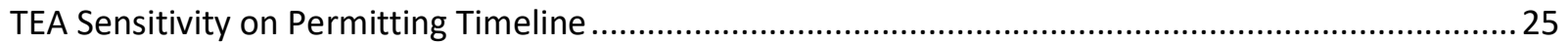




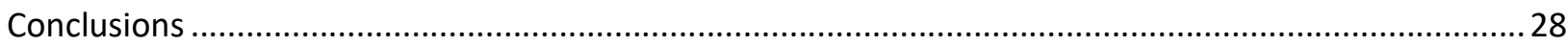

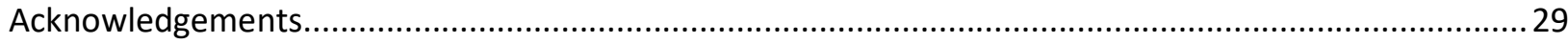

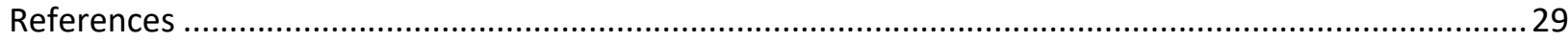

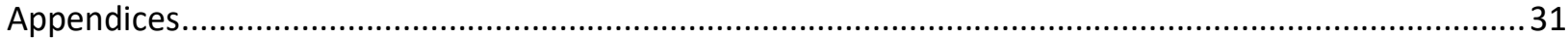




\section{List of Tables}

Table 1. Study sites in Imperial (CA), Churchill (NV), and Beaver (UT) Counties. 5

Table 2. Generalized environmental management/review scenarios impacting permitting timelines. 9

Table 3. Lead and responsible agencies for permitting and environmental review process in Imperial

County, California.

Table 4. Conditional Use Permit and development timelines and project costs for Hudson Ranch - I. 13

Table 5. Conditional Use Permit and well drilling timelines and associated costs for Hudson Ranch - II. 14

Table 6. Costs associated with various exploration activities in Truckhaven GLA. 16

Table 7. Timelines and approximate costs of Enel's Salt Wells geothermal power plant. 20

Table 8. Permitting and exploration timelines of Ormat's Dixie Meadows Geothermal Site. 22

Table 9. Permitting, exploration, and development timelines for a hypothetical geothermal project in

Salton Sea KGRA.

Table 10. Different cost data based on CEQA/NEPA review timelines. 27 


\section{List of Figures}

Figure 1. Generalized permitting timelines and costs that occur to most of the geothermal development activities. For simplicity, all regulatory permitting issues (cultural, environmental, biological, etc.) are lumped together. In reality however, various permitting issues may require separate application to certain local, state, and federal agencies with each having their own processing timeline and cost.......... 6 Figure 2. KGRAs in Imperial County, CA. KGRAs with existing power plants are shown in red. One prospective geothermal site used in this study is shown in green. The County map and locations of KGRAs are modified from Imperial County Report (Imperial County, 1982)............................................10

Figure 3. Permitting and CEQA review timelines for Hudson Ranch - I...............................................13

Figure 4. Permitting and CEQA review timeline for Hudson Ranch - II............................................... 14

Figure 5. Detailed timeline of Hudson Ranch - II CEQA review process. ..............................................15

Figure 6. Detailed timelines of various permitting and exploration activities of LEA-IAE project in

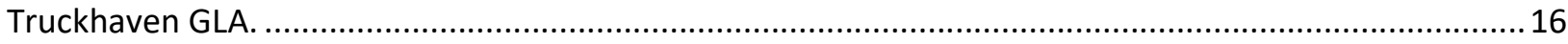

Figure 7. Timelines of CEC certification process for Blackrock 1-2-3 project in Salton Sea KGRA..............17

Figure 8. Timelines ongoing permitting reviews of CTR's Hell's Kitchen project.....................................18

Figure 9. Locations of KGRAs in Churchill and Washoe Counties, NV. Geothermal sites in Salt Wells and

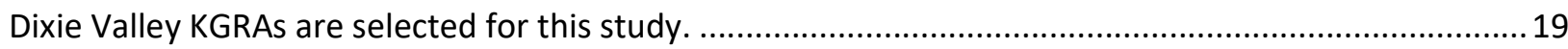

Figure 10. Permitting and development timelines of Enel's Salt Wells geothermal power plant..............20

Figure 11. Permitting and exploration timelines of Ormat's Salt Wells geothermal site.........................21

Figure 12. NEPA review timelines for drilling and testing (blue box in Table 8) on land leased to Ormat for Dixie Meadows Geothermal Project.

Figure 13. NEPA review timelines for developing utilization facilities (red box in Table 8) on land leased to Ormat for Dixie Meadows Geothermal Project. The approval of final EA is still pending. ...................22

Figure 14. Locations of KGRAs in Beaver and surrounding counties in Utah. ........................................23

Figure 15. Timeline of Enel's activities for development of Cove Fort - I geothermal plant. ...................24

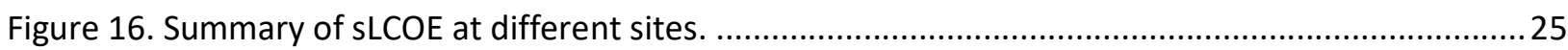




\section{Abbreviations}

AFC: Application for Certification

ARMMP: Aquatic Resources Monitoring and Mitigation Plan

BIA: Bureau of Indian Affairs

BLB: Bud L Bonnett

BLM: Bureau of Land Management

CA: California

CBD: Center for Biological Diversity

CDOT: California Department of Transportation

CalEPA: California Environmental Protection Agency

CalGEM: Geologic Energy Management Division

CDFW: California Department of Fish and Wildlife

CDPR: California Department of Parks and Recreation

CDWR: California Department of Water Resources

CDTSC: California Department of Toxic Substances Control

CEC: California Energy Commission

CEQA: California Environmental Quality Act

CNAHC: California Native American Heritage Commission

CPUC: California Public Utilities Commission

CRBC: Colorado River Board of California

CSLC: California State Lands Commission

CTR: Controlled Thermal Resources

CU: Casual Use

CUP: Conditional Use Permit

CWA: Clean Water Act

CX: Categorical Exclusion

DEIR: Draft Environmental Impact Report

DNA: Determination of NEPA Adequacy

DOE: Department of Energy

DOD: Department of Defense

EA: Environmental Assessment

EEC: Environmental Evaluation Commission 
EIR: Environmental Impact Report

EIS: Environmental Impact Statement

FEIS: Final Environmental Impact Statement

FONSI: Findings of No Significant Impact

FORGE: Frontier Observatory for Research in Geothermal Energy

GRDA: Geothermal Resources Development Account

GTO: Geothermal Technologies Office

IS: Initial Study

IAE: Iceland America Energy

ICAPCD: Imperial County Air Pollution Control District

ICPDS: Imperial County Planning and Development Services

ICPW: Imperial County Public Work

IID: Imperial Irrigation District

KGRA: Known Geothermal Resource Area

LCE: Lithium Carbonate Equivalent

LEA: Layman Energy Associates

LMP: Land Management Plan

NEPA: National Environmental Policy Act

NGS: Nevada Geothermal Specialists

NOD: Notice of Determination

NOI: Notice of Intent

NOP: Notice of Preparation

NPV: Net Present Value

NV: Nevada

O\&M: Operation and Maintenance

PPA: Power Purchase Agreement

RMP: Resource Management Plan

SEAT: Socio-Economic Assessment Tool

SPPE: Small Power Plant Exemption

SUP: Special Use Permit

TEA: Techno-economic Analysis

TGLA: Truckhaven Geothermal Leasing Area 
TG: Thermal Gradient

USACE: United States Army Corp of Engineers

USEPA: United States Environmental Protection Agency

USFS: United States Forest Service

USFWS: United States Fish and Wildlife Service

UTSHPO: Utah State Historic Preservation Office

WOTUS: Waters of the United States 


\section{Executive Summary}

The United States has great geothermal power potential; however, only a small fraction of this resource has been utilized for power generation. Various barriers, including technical, financial, and regulatory permit delays, are attributed to the lower penetration of geothermal energy into the national grid. Unpredictable environmental reviews and permitting timelines are some of the non-technical barriers that can cause delays in geothermal exploration and utilization plans. This document provides an assessment of the potential economic impact of permitting costs and timelines on geothermal power in California, Nevada, and Utah.

Development of geothermal resources requires multi-layered regulatory permitting by local, state, and federal agencies. In this study, we collected and reviewed permit timelines and associated cost data for several existing geothermal power plants as well as for geothermal projects currently undergoing permitting processes for exploration and development activities in California, Nevada, and Utah. We interviewed several geothermal developers and staff from multiple permitting agencies to obtain insight from both sides (i.e., people applying for permits and people processing those applications for California Environmental Quality Act [CEQA] and National Environmental Policy Act [NEPA] reviews and other regulatory compliance). The intent of this project was also to identify informative pathways for the geothermal stakeholder community by which the permitting process could be streamlined.

The review of collected data revealed that the permitting timelines can vary from six months to several years, depending on the presence or absence of biological resources, cultural resources, and sensitive environmental issues at the project site. For developers, each lengthy permitting requirement could be a potential cause for project delays. However, for regulators, the rather lengthy review process means taking time to look at all potential adverse effects that the future project could have on environmental, biological, and cultural resources and develop mitigation measures. During interviews, it was apparent that developers are cognizant of the potentially lengthy permitting process. For projects where there are biological, cultural, or environmental concerns, the permitting process can be frustratingly slow and unpredictably lengthy for developers. This process can take more time if the project area requires permitting and approval of mitigation measures from multiple agencies. Legal challenges to the review processes or the decision records can unpredictably increase permitting timelines. In general, this study indicated that both developers and regulators intend to avoid or minimize potential future litigations to the review processes or the decision records. For example, interviews with Imperial County staff and developers in the Salton Sea Known Geothermal Resource Area (KGRA) revealed a recent need to conduct lengthier CEQA reviews, even for the projects that would have only required lower level CEQA review documents in the past, to avoid potential legal challenges from unions.

The assembled data and information from interviews were used to conduct a quantitative assessment of economic impacts from the permitting cost and timeline on the price of produced geothermal electricity. We conducted a techno-economic analysis (TEA) using cost and the timeline to complete the permitting process and resource development. We calculated the simplified levelized cost of electricity (sLCOE) values for three existing power plants and one geothermal project that completed all permitting processes but did not build the power plant. The calculated SLCOE values for the three existing power plants are about \$54 per MWh (Salt Wells), \$70 per MWh (Cove Fort-I), and \$99 per MWh (Hudson Ranch - I). The environmental review and permitting of these projects occurred relatively faster (within about two years or less) because of the lack of significant issues with environmental, biological, and 
cultural resources in these geothermal sites. Among these projects, the main factor causing variation in sLCOE was the difference in capital cost.

To evaluate the various environmental management and permit review processes that can drastically change the project timeline, we considered a hypothetical geothermal project in the Salton Sea KGRA. Because of the variety of the biological and environmental issues and the involvement of local, state, and federal agencies with overlapping jurisdictions, this project could resemble one of the four (or more) CEQA/NEPA review scenarios, which range from least to most complex in its circumstances. Although the project is a hypothetical, the permitting scenarios considered largely mimic the CEQA/NEPA review processes that either occurred during permitting some of the previous projects or represent ongoing permitting processes of current projects in the area. The fastest CEQA/NEPA review timelines would have the project completed in six years, with a permitting review scenario in which the geothermal development would occur within a designated geothermal development area that has an existing Programmatic Environmental Impact Report (PEIR) and no significant environmental resources or cultural issues. In contrast, the project would take 13 years to complete if it were located in an area with significant environmental resources or cultural issues that required permitting from various agencies. It is important to note that the longest project completion timeline considered is arbitrary and the permitting for any given project could take more than 13 years. Unless the permitting process is fasttracked either by streamlining the review process to an agency or by exemption (e.g., CEQA exemption), it would be difficult to add any new geothermal power to California Public Utilities Commission (CPUC) by 2026 as demanded in the recent Procurement Order to procure $1000 \mathrm{MW}$ from geothermal, even if the permitting process is started now.

In addition to the increasing project completion timelines, the sLCOE values with longer CEQA/NEPA review timelines are 4 to $11 \%$ higher when compared to the SLCOE value with the fastest CEQA/NEPA review timeline. A more prominent adverse economic impact from the increasing permitting timeline is the loss of $\$ 64$ million to $\$ 227$ million in potential revenue in present value that the developers could have otherwise generated if the project could be completed sooner with the fastest review scenario. The potential loss of such revenue could bar developers from enticing investors and result in a project failure. 


\section{Introduction}

Both the U.S. Geological Survey (Williams et al., 2008) and GeoVision (USDOE, 2019) studies show the presence of a substantial geothermal power generation potential in the United States, but only a small fraction of that potential has been developed. Various barriers, such as technical, financial, and regulatory hurdles and delays, are attributed to lower penetration of geothermal energy into the national grid (Richard, 2012; Young et al., 2014; Young et al., 2019; USDOE, 2019). Particularly, the nontechnical barriers that cause delays in exploratory activities and ultimately in siting power plants at prospective geothermal sites are unpredictable permitting and multi-layered environmental regulatory approval timelines associated with local, state, and federal agencies. Besides the costly technical risks, such as well failures, the financial burden associated with unpredictable permitting and regulatory approval timelines has been identified as one of the major discouraging factors in developing and increasing contributions of geothermal resources into the national electricity portfolio.

In general, the technological risks decline along with the maturation of technology, which helps to increase adoption and cost reduction. The technological improvements, such as double flash, triple flash, hybrid geopressure/geothermal, and binary plant designs, have allowed an expansion of installed geothermal capacity (Bertani, 2016). Similarly, technological advancement in geothermal exploration and subsurface engineering capabilities are slowly occurring. Changes in legislation, such as the Energy Policy Act of 2005 and the Energy and Natural Resources Act of 2017, also attempted to increase opportunities for geothermal development by modifying how royalties are calculated, how land is leased; these legislative changes also provided tax incentives and loan guarantees for certain types of renewable energy resources in an effort to make geothermal (and other renewable resources) more competitive with fossil fuel-based electrical power generation. Despite these advancements, the high upfront geothermal exploration and development costs as well as the risk of failures are still steep for the wider use of geothermal resources for power generation.

From early efforts to obtain land access and land lease for exploration to large investments for developing well fields and building power plants, the developers must go through multiple permitting processes for site exploration, drilling, and construction. In many instances, the developers need to make significant investment without having a clear picture of how long it can take to obtain the approval(s) or whether they will eventually obtain the permit to complete the geothermal power plant or the supporting infrastructures (e.g., transmission lines). Therefore, the potential impacts of these non-technical barriers can range from developers abandoning the geothermal development from a site to making the product (e.g., electricity) more expensive and uncompetitive in the market.

In addition to market forces (e.g., power purchase agreement and financial), many previous studies (e.g., USGAO, 2013, Levine et al., 2013; Levin and Young, 2017a, b; Young et al., 2019, USDOE, 2019; Neupane et al., 2022) have identified land access delays, permits, and environmental assessments as non-technical barriers (collectively referred to here as permit barriers). As a part of the GeoVision study (USDOE, 2019), Young et al. (2019) describe various permit barriers such as cultural and tribal, environmentally sensitive, biological resources, land ownership, federal and state leasing, and military facilities. They also note that the permitting timelines also depend on who and how many regulatory frameworks (i.e., local, state, and federal) are involved in the approval processes. In many instances, the environmental assessment (EA) as a part of the National Environmental Policy Act (NEPA) invokes multiple environmental review processes from different agencies (and during different phases of 
development), causing delays and increasing risks to developers (Young et al., 2014). This ultimately impedes greater penetration of geothermal technology as an economic and competitive carbon-free resource for electricity generation. In California, an added state regulatory requirement, California Environmental Quality Act (CEQA) review, must be completed. As stated above, wider adoption of any given technology will gradually make it more efficient with subsequently diminishing risks. In the case of geothermal energy where technological barriers remain paramount, lessening the adverse impact from non-technical barriers could help foster advancement in technical maturity and decrease technical risks as well.

The U.S. geothermal industry has been raising the issues of multi-pronged, non-technical barriers for the adoption of geothermal power (Richard, 2012). Evidently, despite the vast potential to generate electricity, the non-technical barriers, along with the technical difficulties and associated risks, have impeded the larger penetration of geothermal energy. In the past, USDOE/Geothermal Technologies Office (GTO) has sponsored many research programs to identify these non-technical barriers. As a result, the geothermal industry and promoting agencies (e.g., USDOE/GTO) have identified several barriers, and developed strategies/scenarios to overcome those barriers. To evaluate the impact of these nontechnical barriers on the development of geothermal power, the GeoVision study (USDOE, 2019) used various permitting timeline scenarios, ranging from a business-as-usual timeline to disruptive improvements in timelines. The GeoVision Report (USDOE, 2019) and its supporting documents (e.g., Young et al., 2019) showed that with each progressive improvement in permit timelines, the share of geothermal power in the overall national electricity portfolio could expand over the next several decades. Qualitatively, increasing efficiency by decreasing processing timelines to obtain land access, permitting, and environmental reviews improves the overall financial position, shortens the period for return on investment thereby improving project net present value (NPV), and makes geothermal energy more competitive.

Although the research community has made progress on qualitative assessment of the adverse effects of non-technical barriers on the economy of geothermal power, we still lack the quantitative assessment of these barriers' impact on the cost of geothermal electricity at a plant level. In this study, we conducted a quantitative assessment of the financial burden incurred by developers resulting from the permitting processes by evaluating permit timelines and associated cost data under various environmental management scenarios in California, Nevada, and Utah. Using the permit timeline examples from previous projects and ongoing geothermal projects, we built multiple environmental management and CEQA/NEPA review scenarios. These review scenarios vary with presence or absence of existing land use plan, programmatic environmental review documents, and environmental, biological, and cultural issues. Assuming constant, prevailing technological costs and financial mechanisms, we evaluated the impact of various permit timelines on simplified levelized cost of electricity (sLCOE) and revenue generation.

\section{Project Objectives}

The objective of this study was to conduct quantitative evaluation [techno-economic analysis (TEA)] on the impact of geothermal permit timelines on the cost of produced electricity. The project used historical permit timeline data and associated permitting costs to establish geothermal power plants. For some selected cases, the TEA was conducted with actual permit timeline scenarios and available cost data. Originally, we intended to conduct a TEA of existing geothermal power plants representing each 
decade since 1970s. However, because of the lack of permitting data of older power plants and consistency of NEPA/CEQA review process for pre-Hudson Ranch - II (at least in the Salton Sea KGRA), the decadal TEA could not be conducted. Instead, a hypothetical case representing geothermal development in the Salton Sea KGRA was used to compare TEA results with different environmental management scenarios where the permitting timeline could be impacted by the presence or absence of programmatic NEPA/CEQA review documents and biological, environmental, and cultural resources at the project site. The modeled scenarios ranged from a scenario with no complexity in review and permitting process to scenarios with increasingly complex review processes, resulting in longer permit timelines. The complexity in modeled environmental scenarios increases with the presence of biological, environmental, and/or cultural resources at the project site. The presence of these resources typically triggers requirements for permitting reviews from multiple agencies because of the overlapping jurisdictions over the project area.

\section{Approach and Methodology}

\section{Permitting Data}

The study reviewed state-wise regulatory frameworks related to land leasing and permitting issues for the exploration and development of geothermal energy in California, Nevada, and Utah. Multiple geothermal sites with existing power production facilities or with ongoing leasing, exploration, and development permitting activities were selected for this study (Table 1).

Table 1. Study sites in Imperial (CA), Churchill (NV), and Beaver (UT) Counties.

\begin{tabular}{|c|c|c|c|c|}
\hline County (State) & $\begin{array}{l}\text { Geothermal } \\
\text { Project/Site }\end{array}$ & Project Phase & Data Availability & Level of TEA \\
\hline \multirow[t]{5}{*}{ Imperial (CA) } & $\begin{array}{l}\text { Hudson Ranch-I } \\
\text { (Salton Sea KGRA) }\end{array}$ & $\begin{array}{l}\text { Complete with commission of } \\
\text { power plant }\end{array}$ & $\begin{array}{l}\text { Permit timelines } \\
\text { and costs }\end{array}$ & LCOE, sLCOE \\
\hline & $\begin{array}{l}\text { Hudson Ranch-II } \\
\text { (Salton Sea KGRA) }\end{array}$ & $\begin{array}{l}\text { Permitting and regulatory } \\
\text { requirements completed, some } \\
\text { injection/production wells drilled, } \\
\text { no power plant }\end{array}$ & $\begin{array}{l}\text { Permit timelines } \\
\text { and partial costs }\end{array}$ & LCOE, sLCOE \\
\hline & Truckhaven-LEA & $\begin{array}{l}\text { Permitting and regulatory } \\
\text { requirements partially completed; } \\
\text { exploratory deep well drilled }\end{array}$ & $\begin{array}{l}\text { Partial permit } \\
\text { timelines and } \\
\text { partial costs }\end{array}$ & \\
\hline & $\begin{array}{l}\text { Blackrock 1-2-3 } \\
\text { (Salton Sea KGRA) }\end{array}$ & $\begin{array}{l}\text { Permitting and regulatory } \\
\text { requirements completed; no } \\
\text { wellfield or power plant } \\
\text { development }\end{array}$ & Permit timelines & \\
\hline & Hell's Kitchen (CTR) & $\begin{array}{l}\text { Partial permitting and regulatory } \\
\text { requirements completed }\end{array}$ & $\begin{array}{l}\text { Partial permit } \\
\text { timelines }\end{array}$ & \\
\hline \multirow[t]{2}{*}{ Churchill (NV) } & Salt Wells, Enel & $\begin{array}{l}\text { Complete with commission of } \\
\text { power plant }\end{array}$ & $\begin{array}{l}\text { Timeline and } \\
\text { partial costs }\end{array}$ & LCOE, sLCOE \\
\hline & $\begin{array}{l}\text { Dixie Meadows, } \\
\text { Ormat }\end{array}$ & $\begin{array}{l}\text { Partial permitting and regulatory } \\
\text { requirements completed }\end{array}$ & $\begin{array}{l}\text { Partial permit } \\
\text { timelines }\end{array}$ & \\
\hline \multirow[t]{2}{*}{ Beaver (UT) } & Cove Fort -I & $\begin{array}{l}\text { Complete with commission of } \\
\text { power plant }\end{array}$ & $\begin{array}{l}\text { Permit timelines } \\
\text { and costs }\end{array}$ & LCOE, sLCOE \\
\hline & Cove Fort -II & $\begin{array}{l}\text { Permitting and regulatory } \\
\text { requirements completed, some } \\
\text { injection/production wells drilled, } \\
\text { no power plant yet }\end{array}$ & $\begin{array}{l}\text { Timelines and } \\
\text { partial costs }\end{array}$ & \\
\hline
\end{tabular}


Figure 1 shows a simplified permitting timeline that is likely to occur for most of the geothermal development activities. Some of the steps shown in Figure 1 can occur simultaneously (or in a different order than what is shown) and decrease the severity of timeline issues. Literature review and stakeholders (Table A1) outreach efforts were made specifically to collect as much data as possible on each of the steps in Figure 1. For existing geothermal sites, the relevant data, such as permit approval cost, timeline, and available exploration \& development cost, were used to assess the economic impact of permit timelines in terms of sLCOE.

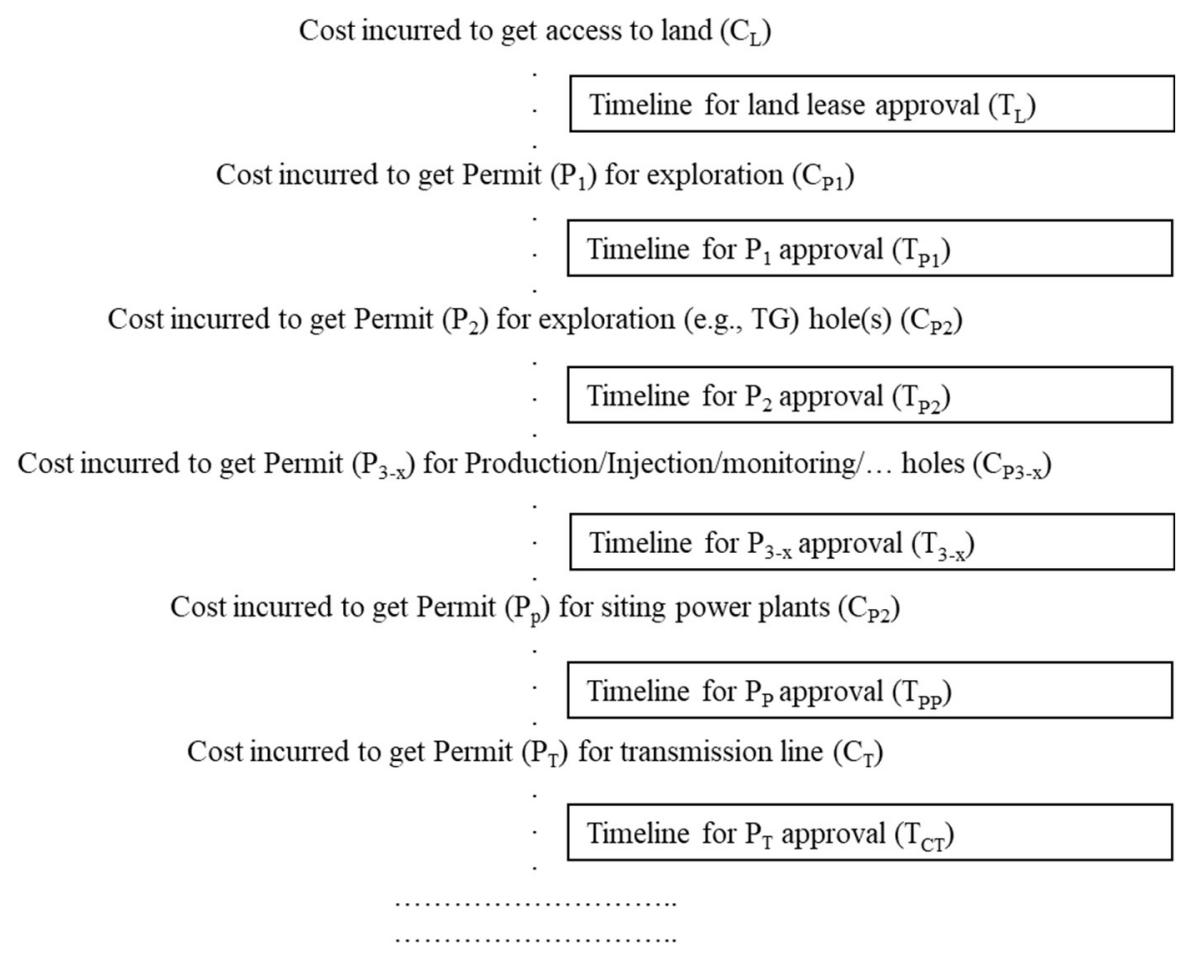

Figure 1. Generalized permitting timelines and costs that occur to most of the geothermal development activities. For simplicity, all regulatory permitting issues (cultural, environmental, biological, etc.) are lumped together. In reality, however, various permitting issues may require separate application to different local, state, and federal agencies with each having their own processing timeline and cost.

\section{Data Reduction and Filling the Data Gap}

NEPA/CEQA review and various ancillary permitting documents were collected from agency websites and other publicly available sources. In addition, remote interviews were conducted to obtain timelines/cost data as well as to get insights about the permitting challenges from both developers and regulators. Timeline data were scattered in multiple documents such as public notices, decision records, county board meeting minutes, and in lengthy environmental review documents (e.g., EIA, EIS, EIR, certification document, etc.). A list of document types from different agencies we reviewed to obtain timeline data is given in Table A2 (in Appendix A). Whenever a specific date of an action (e.g., application, review period, approval, etc.) was available, that was used in the TEA. In many instances, however, the exact date of an action is not provided in the documents. In those cases, an estimated date was assigned based on preceding action's date, succeeding action's date, or some other timeline reference point. 
Unlike timeline data, costs incurred to prepare, apply, and complete NEPA/CEQA review process for various activities of a project were challenging to acquire or were unavailable. An example is the Imperial County Planning and Development Services (ICPDS) that provided their accounting details related to CEQA review process for conditional use permit (CUP) for both Hudson Ranch - I \& II. The cost data were requested from many developers. However, the details for the costs were hard to obtain. We also reviewed companies' annual reports to get task-specific costs of a project. When available, the company data were mostly an overall project completion cost (e.g., total project cost for Enel's Cove Fort - I). In these cases, the total project cost was assumed to occur at the completion of the project. In some instances, well drilling details and costs were published (e.g., Rickard et al., 2014 for Hudson Ranch - II). When no cost data were available for permitting (from application fee various permitting to NEPA review process), National Renewable Energy Laboratory's (NREL) GeoRePORT Socio-Economic Assessment Tool (SEAT) (GeoReport, 2014; Young and Levine, 2018) was used to estimate permit application fee and CEQA/NEPA review cost. Specifically, we used an Excel-based SEAT developed by Levine and Young (2016) to estimate application fees for ancillary permitting and NEPA review costs when no-specific data were available for some case sites (e.g., Truck Haven-LEA/IAE Project).

\section{Techno-economic Analysis}

Permitting timelines and delays can result in increased costs and contribute to making geothermal energy expensive. To assess the economic impact of these timelines on LCOE, we used Geothermal Electricity Technology Evaluation Model (GETEM, Mines, 2008; 2016) and a project-developed Excelbased TEA tool. Prevailing discount rates, lease/permit timelines and associated costs/loans at each applicable stage (Figure 1) along with various modeling timeline scenarios were used considered while conducting TEA.

\section{Simplified LCOE}

We developed an Excel workbook to conduct TEA by calculating simplified LCOE (sLCOE) using the following equation by Loewen (2020):

$s L C O E=\{($ overnight capital cost $*$ capital recovery factor + fixed $O \& M$ cost $) /(8760 *$ capacity factor $)\}+($ fuel cost * heat rate $)+$ variable O\&M cost

where

overnight capital cost is unit cost of installed kilowatts (in dollars per kW)

fixed O\&M cost is annual fixed operation and maintenance cost (in dollars per installed $\mathrm{kW})$

8760 is the number of hours in a non-leap-year capacity factor is average power output, as percent of maximum capacity

fuel cost is the cost of fuel in $\$ /$ Btu

heat rate is Btu per kWh

Also

$C R F=\left\{d(1+d)^{n}\right\} /\left\{\left[(1+d)^{n}\right]-1\right\}, d=$ discount rate, $n=$ number of annuities 
Project costs from land lease bid bonus to plant construction were converted to their value in the power plant completion year using a $6 \%$ annual discount rate. Time of the geothermal power plants operation was considered as 30 years in all cases and scenarios. Discount rate on the spent cost was assumed to be $6 \%$ in all cases and scenarios. A representative capacity factor of $70 \%$ for geothermal systems (EIA, 2020) was used in all cases. The $70 \%$ capacity factor could be considered as a conservative value for the new geothermal power plants since it is skewed low by older geothermal plants in Geysers, California. The fuel cost for the geothermal plant is assumed to be zero. Both fixed and variable operation and maintenance costs are assumed to be $\$ 0.01 / \mathrm{KWh}$ each. The operation and maintenance (O\&M) cost was chosen as a fixed cost, which is around $10 \%$ of the $\mathrm{SLCOE}$, and $6 \%$ discount rate was chosen as an average of long-term inflation rate ( $2 \%)$ and industrially accepted return on investment ( 10\%). To assess the impact of timelines, sLCOE values were calculated for different timelines.

\section{Potentially Gained or Missed Revenue}

Gained and missed revenues represent the aggregated revenues generated or not-generated from the produced or not-produced electricity from case study sites. Gained or missed revenue is calculated based on the national average price of electricity for that particular year.

\section{Modeling Scenarios}

We developed environmental management and timeline scenarios consistent with scenarios included in GeoVision (USDOE, 2019) and used those timeline scenarios for TEA. The timeline scenarios can vary from one site to another depending on the presence or absence of biological or/and cultural resources and other sensitive issues. Young et al. (2019) identified six separate attributes that have significant impact on land access:

1) Cultural and tribal resources

2) Environmentally sensitive areas

3) Biological resources

4) Land ownership

5) Federal and state lease queue

6) Proximity to military installation

Some areas with high potential for geothermal development are unavailable for development because of existing biological resources or are environmentally sensitive/protective areas. However, this study is primarily based on data from existing power production sites or sites with ongoing exploration/development activities. Thus, we do not include unallowable land access scenarios.

Geothermal exploration and developmental activities in allowable lands require different permits, generally from various agencies. The permitting processes vary from state to state, and even from county to county within some states. However, the most important determining factors in permit timelines for an individual site are whether the site is within a pre-defined geothermal resource area (e.g., KGRA) or not, has an absence or presence of biological or/and cultural resources and other sensitive issues, has several agencies with jurisdiction and overlapping authority to permit and approve mitigation measures, etc. In Imperial County, California, developers can directly apply (if they choose to) for CUP for the development of power plants, if the project site is located within the KGRA since the designation of an area as KGRA satisfies the resource viability in that area. However, for a project site outside of any KGRA, developers must go through the two-step CUP process. In this case, the first CUP 
would let developers conduct exploration by drilling and testing to ensure resource viability. If the resource is viable, the initial exploration CUP would be folded into the second resource utilization CUP.

In addition, Levine et al. (2013) mentioned that permitting delays can occur because of inadequate staff and a lack of subject experts in the permitting agencies. They also noted that vacation schedules of the staff and time of the year when the permit applications are filed can affect permitting timelines. The lack of staff or expertise, overlapping jurisdiction over sensitive issues, lack of (or difficulty in) inter-agency coordination, and other specific examples causing permitting delays were also mentioned by developers during interviews.

Using the information gathered from previous studies (Levine et al., 2013; Young et al., 2014; GeoReport, 2014; Young and Levine, 2018; Young et al., 2019; USDOE, 2019), our assessment of the cases and nature of CEQA/NEPA review process that occurred at various case sites and with the information we obtained from stakeholders, we prepared a list (Table 2) of generalized environmental management/review scenarios likely to occur at different geothermal sites. Specifically, the various environmental management and review scenarios given in Table 2 reflect the CEQA/NEPA review process that occurred (or is occurring) to one (or many) of the geothermal projects in Imperial County, California. Depending upon the presence or absence of prior CEQA/NEPA reviews and biological, environmental, and cultural resources in the potential geothermal project area, the permitting process can have a wide range of permitting timelines, as described in GeoReport (2014). As previously suggested by Levine et al. (2013), each type of scenario given in Table 2 could result in multiple environmental reviews and permitting timelines depending on the lack of or availability of expertise and the existence of prior-knowledge of processing geothermal exploration/development permitting in the Lead Agency with an established mechanism (e.g., memorandum of understanding) between interagencies.

Table 2. Generalized environmental management/review scenarios impacting permitting timelines.

\begin{tabular}{|c|l|}
\hline Types & Scenarios \\
\hline A & $\begin{array}{l}\text { Land Use Plan (LUP) and Programmatic Environmental Impact Statement (PEIS) and/or } \\
\text { Programmatic Environmental Impact Report (PEIR) exist, and no significant environmental } \\
\text { resources or cultural issues identified. }\end{array}$ \\
\hline B & $\begin{array}{l}\text { LUP PEIS/PEIR exist, presence of environmental (species of concern) or cultural issues } \\
\text { where all responsible agencies concur with mitigation approaches of Lead Agency. }\end{array}$ \\
\hline C & $\begin{array}{l}\text { LUP PEIS/PEIR exist, presence of environmental (species of concern) or cultural issues } \\
\text { where many responsible agencies have diverse mitigation approaches, and require } \\
\text { reconciliation. }\end{array}$ \\
\hline D & $\begin{array}{l}\text { LUP PEIS/PEIR exist, presence of major environmental (species of concern) or cultural } \\
\text { issues, petition \& legal challenge. }\end{array}$ \\
\hline E & $\begin{array}{l}\text { LUP or PEIR/PEIS do not exist, may require early steps, e.g., nomination and pre-leasing } \\
\text { reviews. }\end{array}$ \\
\hline
\end{tabular}

Since each existing or ongoing geothermal development project has its own unique review process and timeline, we created a hypothetical geothermal project in the Salton Sea KGRA to assess and compare the impact of various environmental management scenarios (Table 2) on sLCOE. This hypothetical geothermal project was subject to different environmental management and review/permitting processes, resulting in different project completion timelines. Since Imperial County (Lead Agency for 
geothermal development of $<50 \mathrm{MW}$ in the Salton Sea KGRA) has a well-developed CEQA review process, we limited our analysis operating with assumption that the Lead Agency has experienced staff. However, in some environmental modeling scenarios, multiple agencies would require to approve permits satisfying all CEQA, NEPA, and Section 404 of Clean Water Act (CWA), so our assumption could appear rather optimistic.

\section{Land Access and Permitting Data}

\section{Imperial County, California}

Imperial County, California, has been known for its large potential for geothermal energy. Since the 1970s, USGS has identified as many as nine KGRA within this county. At present, Imperial County hosts nearly 20 geothermal power plants in four KGRAs (Figure 2), totaling about $930 \mathrm{MW}$ of power generation. Most of the geothermal power plants in this county were built in the 1980s and 1990s. Despite some of the geothermal development projects having completed all regulatory and permitting requirements, there has been only a few successful development activities since 2000 . Only one new geothermal power plant was built in the county since 2010. Recently, the area has seen an uptick in geothermal development activities. Currently, there are two active projects: one in the exploration phase and another in the development phase. Both projects are getting approval for exploration and developmental activities.

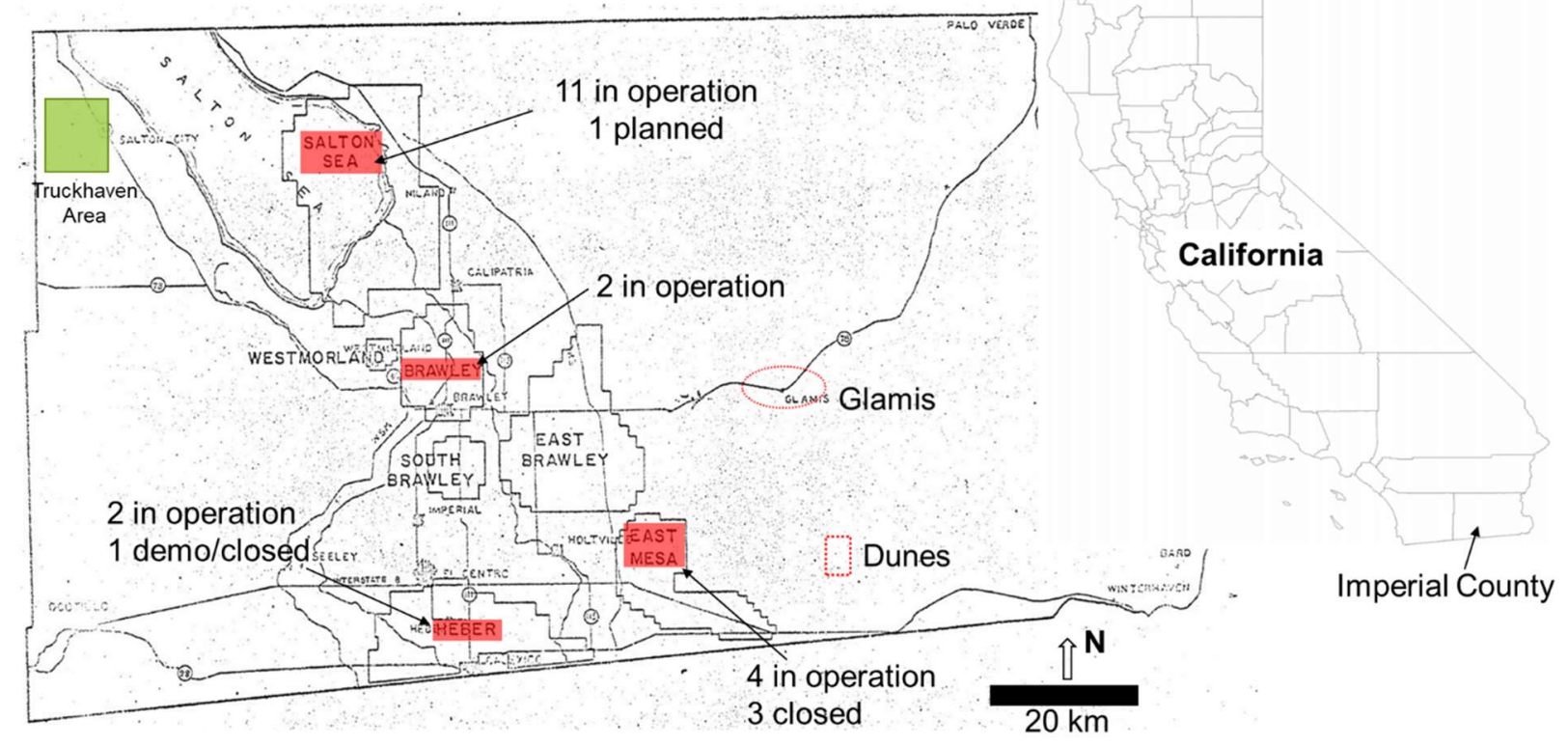

Figure 2. KGRAs in Imperial County, CA. KGRAs with existing power plants are shown in red. One prospective geothermal site used in this study is shown in green. The County map and locations of KGRAs are modified from Imperial County Report (Imperial County, 1982).

\section{Permitting and Reviewing Agencies for Imperial County Projects}

Depending upon the land ownership and size of the proposed geothermal development, one of the three agencies-Imperial County, California Energy Commission (CEC), or Bureau of Land Management (BLM) - can act as the lead agency for reviewing, coordinating, and permitting geothermal-related activities in Imperial County, California. Regardless of the size of the proposed geothermal development 
plant, the BLM acts as the lead agency for leasing, exploration, and development activities on the federal lands. On the state and private lands, CEC is the lead agency for permitting and conducting review processes for exploration and development activities with a designated power production plant larger than $50 \mathrm{MW}$. However, if the designated power production plant is smaller than $50 \mathrm{MW}$, the lead agency is the Imperial County. Most of the individual geothermal power plants in Imperial County are of 49.9 MW or smaller. According to the staff from Imperial County, CEC, and CalGEM, CEC was once busy with the permitting of larger non-geothermal power plants (e.g., fossil fuels or nuclear), so it delegated permitting authority to the county for smaller geothermal power plant developments. To avoid relatively lengthy and costly CEC permitting processes for larger geothermal development, geothermal developers limited their geothermal development within the $50 \mathrm{MW}$ and obtained permitting and CEQA review through the county. Regardless of CEC or the county leading the permitting and CEQA review process, several local, state, and federal agencies take part in the review process as responsible agencies. Various private groups (citizens, organizations, and environmental justice groups, etc.) can also provide comments on the CEQA documents during the review period. Some agencies (e.g., US Army Corp of Engineers in issues related to Section 404 of CWA) where environmental, biological, and/or cultural resources are at stake also have the jurisdiction over those resources and play a critical role in defining the mitigation approaches and permitting the projects. Table 3provides the Lead and Responsible Agencies that generally coordinate and/or provide comments, concerns, and insights into the relevant issues during the permitting and environmental review process.

\section{Selected Study Sites in Imperial County}

For this study, we selected one existing power plant, two geothermal projects that completed regulatory approval processes, and one geothermal project in the process of getting regulatory approvals, and one prospective site with past exploration activities. Table 1provides the selected projects, degree of data availability, and level of TEA conducted for the selected projects in Imperial County.

Originally, we attempted to get the environmental reviews and permitting documents for all existing geothermal power plants in the Imperial County, particularly within the Salton Sea KGRA. However, it became apparent that such data for the older power plants established between the decades of 1970 and 1990 were challenging to obtain. During our meeting with ICPDS, we raised this issue with the ICPDS Director (Mr. Jim Minnick). We were told that such old data could be difficult to locate, and even if found, would be similar in nature to that of the Hudson Ranch - I (commissioned in 2012), which had a fairly straight-forward permitting process, with Initial Study level of CEQA review resulting in Mitigated Negative Declaration (MND) as a decision record. In general, the MND-level of CEQA review could be completed by the county using their regular staff, make the Initial Study report available for comments from responsible agencies and public, incorporate and address comments from responsible agencies and public, and issue MND as a final CEQA document. By definition, issuance of MND assumes that the project will have some impact on the environment that can be minimized or mitigated with recommended measures. After the MND decision, developers could proceed with the exploration and/or developmental activities along with implementing the mitigation measures.

Unlike the previous projects in the Salton Sea KGRA, the Hudson Ranch - II permitting process required preparation of an Environmental Impact Report (EIR), which is a higher level of CEQA review process, in 2012. Akin to the Hudson Ranch - I, the Hudson Ranch - II project was also planned on a nearby deeply disturbed farmland with identical environmental conditions. Initially, the Hudson Ranch - II project also approved with an MND-level of CEQA review document, but it was later subject to an EIR-level of CEQA 
review process because of an appeal to the initial MND decision by labor unions. Furthermore, according to county officials, any future geothermal development activities on the non-federal lands within the Imperial County would likely require CEQA review to the EIR level.

Because of the availability of high-quality permitting data for one case representing the pre-Hudson Ranch - II era, the data collection effort for the older sites were ceased after we conducted an interview with Director of ICPDS. Based on feedback from stakeholders, the economic impact analysis from permitting timelines in the Salton Sea KGRA were limited to two-time frames: pre-Hudson Ranch - II and Hudson Ranch - II (and later).

Table 3. Lead and responsible agencies for permitting and environmental review process in Imperial County, California.

\begin{tabular}{|l|l|l|}
\hline Lead Agency & When/where & Responsible Agencies \\
\hline Imperial County-ICPDS & $\begin{array}{l}<50 \mathrm{MW} \text {, state and/or } \\
\text { private lands }\end{array}$ & $\begin{array}{l}\text { Local: ICAPCD, IID, ICPDS (when CEC is } \\
\text { Leading Agency) }\end{array}$ \\
\hline $\begin{array}{l}\text { California Energy } \\
\text { Commission }\end{array}$ & $\begin{array}{l}>50 \mathrm{MW} \text {, state and/or } \\
\text { private lands }\end{array}$ & $\begin{array}{l}\text { State: CA-EPA, CaIGEM, CA SLC, CA DOT, } \\
\text { CA-DWR, CA- DFW, CA-NAHC, CRBC }\end{array}$ \\
\cline { 1 - 2 } $\begin{array}{l}\text { Bureau of Land } \\
\text { Management }\end{array}$ & Federal lands & $\begin{array}{l}\text { Federal: USEPA, USFS, DOE, DOD, USACE, } \\
\text { BIA } \\
\text { Concerned citizens, organizations, } \\
\text { environmental justice groups }\end{array}$ \\
\hline
\end{tabular}

\section{Hudson Ranch - I, Salton Sea KGRA}

Hudson Ranch - I (currently known as JL Featherstone Plant), owned and operated by EnergySource, is located in Salton Sea KGRA. EnergySource started the developmental activities with the submission of a CUP application to the ICPDS in 2006. The CUP application intended to drill up to seven production and injection wells with the construction of two well pads, geothermal power plants, including brine processing and turbine-generator facilities, and a 92-kV transmission line. After county received the CUP application, it started CEQA review process. It took about 14 months to complete the CEQA review process and approval with MND (Figure 3). During the CEQ review process, county received a comment from California Native American Heritage Commission (CNAHC). The review comment from CNAHC mainly stated the legal requirement to protect the Sacred Sites and articles of cultural importance to tribes. It suggested consulting with local tribes to avoid unanticipated discoveries of cultural resources or burial sites in the project area.

Table 4 provides the cost associated with the CUP and completion of the project. The wellfield, plant, and transmission line development started in 2008. Figure B1 (in Appendix B) shows the timelines for application, approval, drilling start, and drilling completion for several wells of this project. 


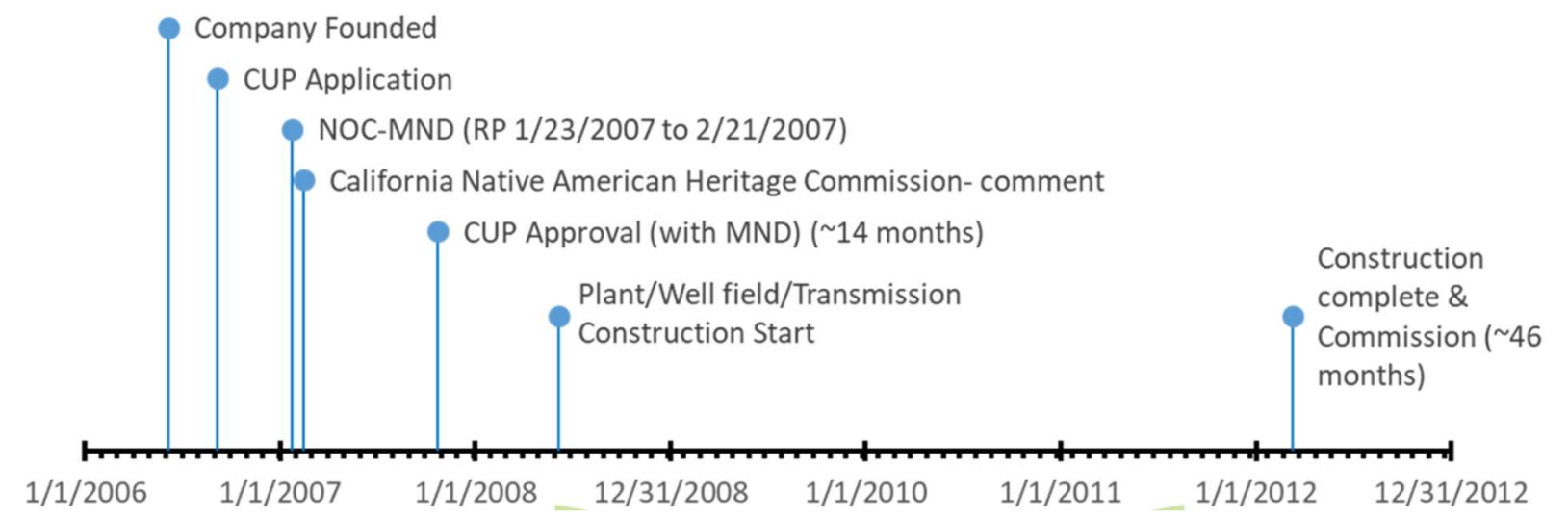

Figure 3. Permitting and CEQA review timelines for Hudson Ranch - I.

Table 4. Conditional Use Permit and development timelines and project costs for Hudson Ranch - I.

\begin{tabular}{|c|c|c|c|c|c|}
\hline \multicolumn{6}{|c|}{$\begin{array}{l}\text { Hudson Ranch I/Energy Source } \\
\text { Power Capacity 49.9 MWe } \\
\text { CUP \# 06-0047 } \\
\text { California Clearing House \# } 2007011097 \\
\end{array}$} \\
\hline & \multicolumn{3}{|c|}{ CUP-CEQA $^{1}$} & \multicolumn{2}{|c|}{ Wellfield/Plant/Transmission } \\
\hline & Application & NOC-MND ${ }^{2}$ & MND Approval & Start & Complete \\
\hline Dates & $9 / 6 / 2006^{3}$ & $1 / 23 / 2007$ & $10 / 23 / 2007$ & $6 / 6 / 2008$ & $3 / 9 / 2012$ \\
\hline Timelines (month) & \multicolumn{3}{|c|}{13.7} & \multicolumn{2}{|c|}{45.7} \\
\hline Cost & \multicolumn{3}{|c|}{$\$ 5,915^{4}$} & \multicolumn{2}{|c|}{$\$ 414,000,000^{5}$} \\
\hline \multicolumn{6}{|c|}{$\begin{array}{l}\text { 1. Conditional Use Permit, triggered CEQA review for the project. } \\
\text { 2. Notice of completion of CEQA review process with Mitigated Negative Declaration. } \\
\text { 3. Exact date not found. } \\
\text { 4. Cost data from ICPDS. } \\
\text { 5. Cost data from EnergySource. }\end{array}$} \\
\hline
\end{tabular}

\section{Hudson Ranch - II, Salton Sea KGRA}

EnergySource applied for CUP for their second geothermal project (Hudson Ranch - II) in 2010. The general timelines of this permitting and CEQA review process is presented in Figure 4 and Table 5. As shown in Figure 4, the initial CUP application and CEQA review of the project approved within 5 months with MND. However, this decision was appealed by unions, and ICPDS had to conduct a full-scale CEQA review with preparation of an EIR.

During interviews with both developers and regulators, two unions-California Union for Reliable Energy (CURE) and Labor Union International (LIUNA) - are mentioned as entities that are generally expected to appeal and challenge the CEQA review decisions. Both regulators and developers agree that no matter how well the CEQA review was conducted, mitigation measures were developed, and informed decisions were made, there always remain some challengeable aspects such as depth and range of review/analysis conducted, how and who conducted the background studies, and so on. Unions find these challengeable aspects and use them to appeal and challenge the review process, mostly to have 
project-labor agreements in their terms. Consequently, these appeals and challenges can add between one to one-and-a-half years to a project, as happened with the Hudson Ranch - II.

Once ICPDS started comprehensive CEQA review process, a second co-located project (Simbol Materials' lithium extraction) was combined with the Hudson Ranch - II for the CEQA review. For both projects, the CUP was approved in 2012, after 26 months (Figure 5). Figure B2 shows the timelines for application, approval, drilling start, and drilling completion for several wells in the Hudson Ranch - II project. Ultimately, the project did not move forward beyond exploration drilling.

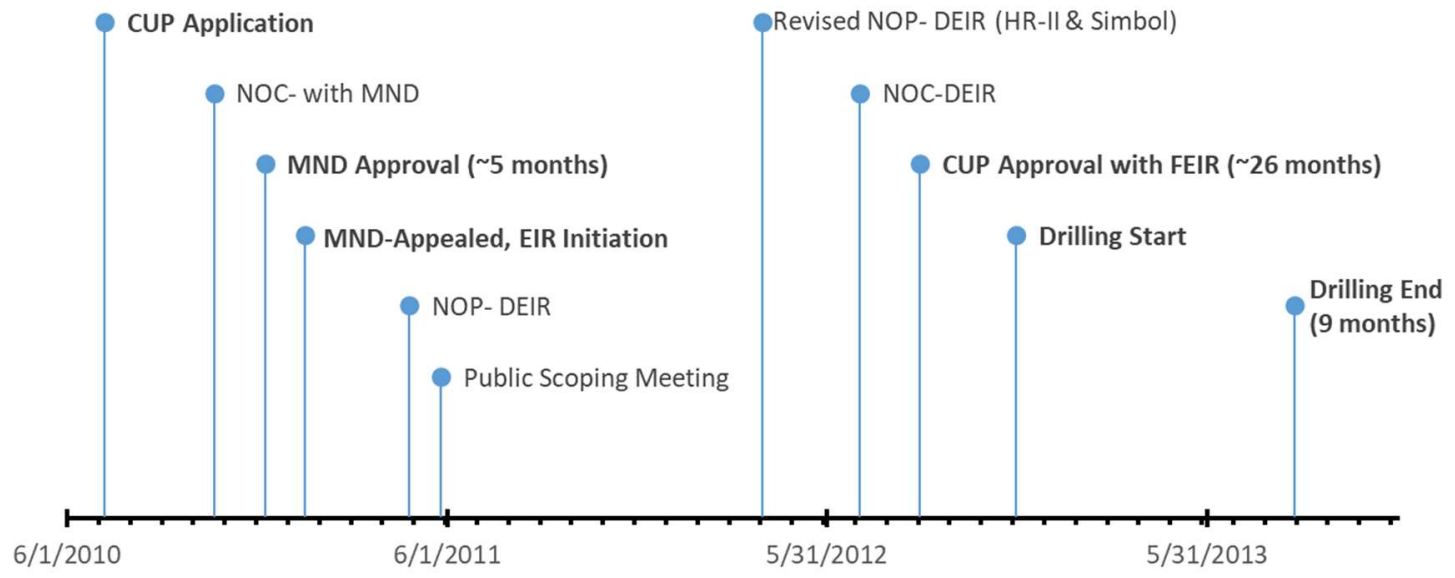

Figure 4. Permitting and CEQA review timeline for Hudson Ranch - II.

Table 5. Conditional Use Permit and well drilling timelines and associated costs for Hudson Ranch - II.

\begin{tabular}{|c|c|c|c|c|c|c|c|c|c|}
\hline \multicolumn{10}{|c|}{$\begin{array}{l}\text { Hudson Ranch II \& Simbol II Lithium Plant } \\
\text { Power Capacity: 49.9 MW } \\
\text { HRP-II CUP \# G10-0002/Simbol II CUP\#12-0005 } \\
\text { California Clearing House \# 2010101065 }\end{array}$} \\
\hline \multirow[t]{2}{*}{ Steps } & \multicolumn{7}{|c|}{ CUP/CEQA } & \multicolumn{2}{|c|}{ Drilling } \\
\hline & App & \begin{tabular}{|l|l|} 
NOC - MND & MND Apv \\
\end{tabular} & MND-Apd & \begin{tabular}{|l|l|} 
NOP- DEIR & Scoping \\
\end{tabular} & Re NOP - DEIR & NOC-DEIR & CUP Apv with EIR & Start & End \\
\hline Dates & $7 / 7 / 2010$ & \begin{tabular}{|l|l|}
$10 / 20 / 2010$ & $12 / 8 / 2010$ \\
\end{tabular} & $1 / 15 / 2011$ & \begin{tabular}{|l|l|}
$4 / 26 / 2011$ & $5 / 26 / 2011$ \\
\end{tabular} & $3 / 30 / 2012$ & $7 / 2 / 2012$ & $8 / 29 / 2012$ & $11 / 29 / 2012$ & $8 / 24 / 2013$ \\
\hline Timelines (months) & \multicolumn{7}{|c|}{26.1} & \multicolumn{2}{|c|}{8.933} \\
\hline Costs & \multicolumn{7}{|c|}{$\$ 729,006$} & \multicolumn{2}{|c|}{$\$ 7,150,000$} \\
\hline \multicolumn{10}{|c|}{$\begin{array}{l}\text { App: Application; NOC-MND: Notice of Completion-Mitigated Negative Declaration; Apv: Approved; Apd: Appealed; NOP-DEIR: Notice of Preparation-Draft } \\
\text { Environmental Impact Report; Re: Revised. }\end{array}$} \\
\hline
\end{tabular}



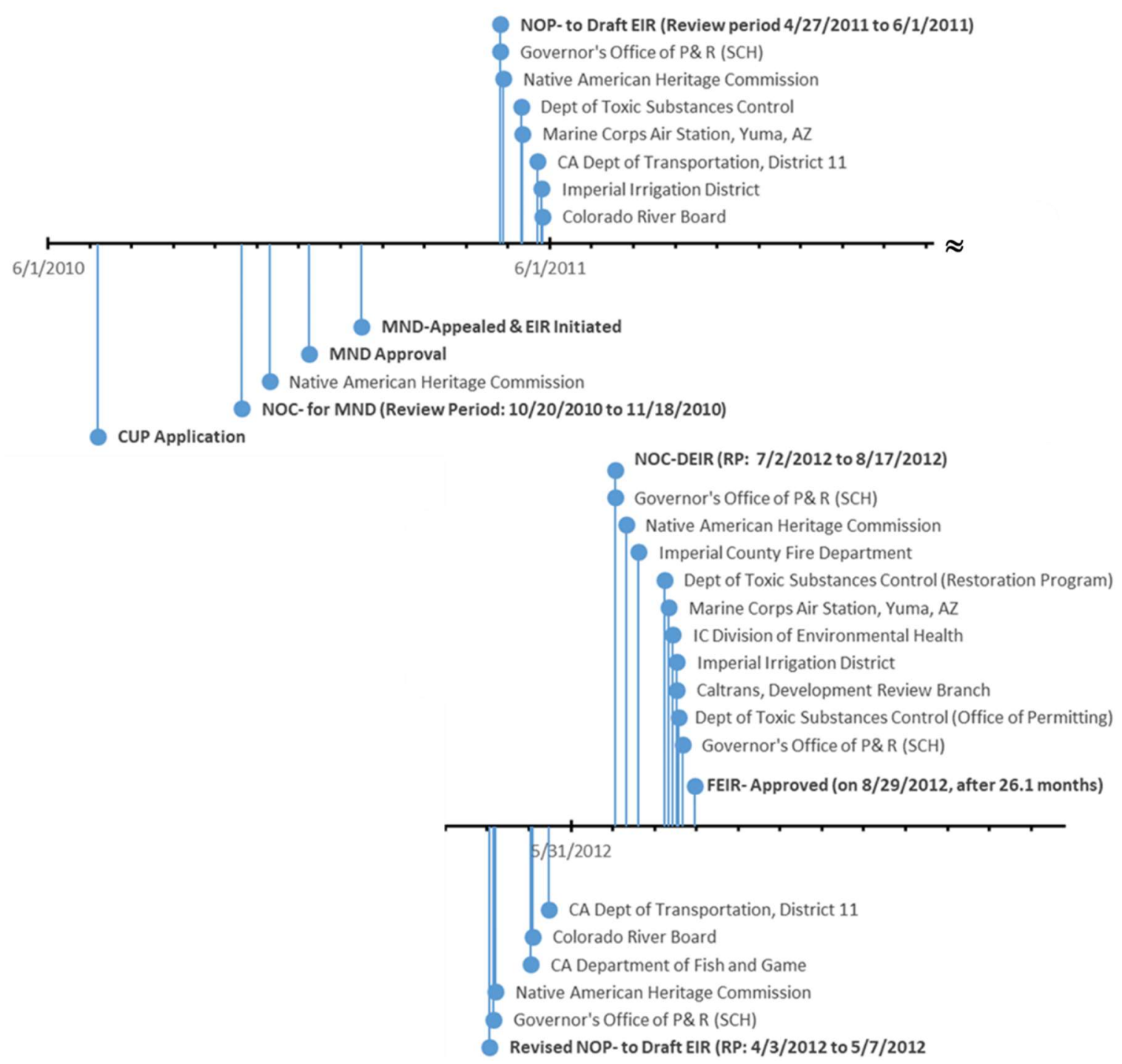

Figure 5. Detailed timeline of Hudson Ranch - II CEQA review process.

\section{Truckhaven Geothermal Leasing Area}

Several companies conducted geothermal exploration work in the Truckhaven Geothermal Area, which is located to the west of Salton City town in the northwestern part of Imperial County. This resource area has a complex land ownership structure with parcels managed by federal, state, and private entities. Also, Ocotillo Wells State Vehicle Recreation Area is located nearby this resource area. In 2007, BLM defined this area as Truckhaven Geothermal Leasing Area (TGLA) and prepared a programmatic EIS with a goal of facilitating geothermal leasing, exploration, and developmental activities.

Earlier geothermal exploration efforts included geological and exploratory well drilling in the area. In 1982, Phillips Petroleum drilled a deep well in the area and verified a viable geothermal resource. Later, Union Oil and others leased state/school lands in this area for additional exploratory works, including deep drilling. 


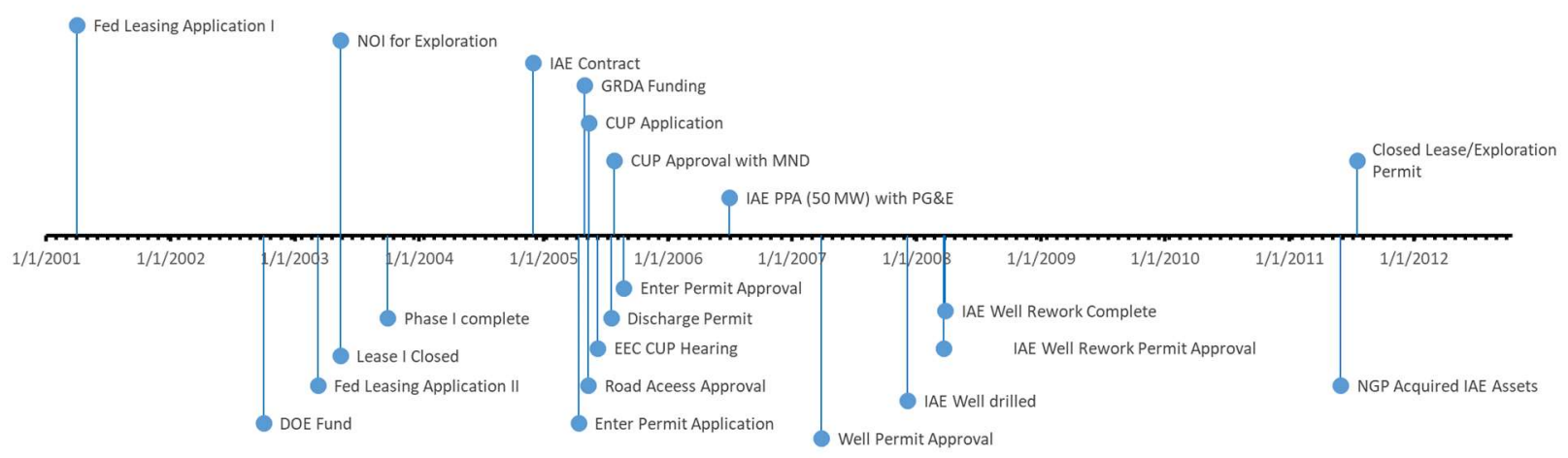

Figure 6. Detailed timelines of various permitting and exploration activities of LEA-IAE project in Truckhaven GLA.

Table 6. Costs associated with various exploration activities in Truckhaven GLA.

\begin{tabular}{|c|c|c|c|c|c|c|}
\hline & \multicolumn{6}{|c|}{ Phase I: Exploration } \\
\hline Action & $\begin{array}{c}\text { Fed Leasing } \\
\text { Application } \\
\text { I }\end{array}$ & $\begin{array}{l}\text { Fed Leasing } \\
\text { Application II }\end{array}$ & $\begin{array}{c}\text { NOI for } \\
\text { Exploration\# }\end{array}$ & $\begin{array}{l}\text { Additional } \\
\text { Permits* }\end{array}$ & $\begin{array}{l}\text { Geological } \\
\text { Exploration }\end{array}$ & $\begin{array}{c}\text { Total Phase I } \\
\text { Cost }\end{array}$ \\
\hline Agency & BLM & BLM & BLM & Various & LEA & LEA \\
\hline Dates & $4 / 2 / 2001$ & $3 / 10 / 2003$ & $5 / 15 / 2003$ & & & $9 / 30 / 2003$ \\
\hline \multirow[t]{2}{*}{ Cost } & $\$ 830$ & $\$ 415$ & $\$ 10,000$ & $\$ 4,000$ & $\$ 391,100$ & $\$ 405,100$ \\
\hline & \multicolumn{6}{|c|}{ Phase 2: Exploration } \\
\hline \multirow[t]{2}{*}{ Action } & \multicolumn{2}{|c|}{ Enter Permit } & Road Access & \multicolumn{2}{|c|}{ CUP } & \multirow{2}{*}{$\begin{array}{c}\text { Application: } \\
\text { Discharge } \\
\text { Permit }\end{array}$} \\
\hline & Application & Approval & Approv & Application & $\begin{array}{l}\text { Approval } \\
\text { with MND }\end{array}$ & \\
\hline Agency & CDPR & CDPR & ICPW & ICPDS & ICPDS & ICPDS \\
\hline Dates & $4 / 14 / 2005$ & $8 / 25 / 2005$ & $5 / 13 / 2005$ & $5 / 15 / 2005$ & $7 / 27 / 2005$ & $7 / 19 / 2005$ \\
\hline Cost & \multicolumn{2}{|c|}{$\$ 1,500$} & $\$ 1,500$ & \multicolumn{2}{|c|}{$\$ 6,000$} & $\$ 1,500$ \\
\hline \multicolumn{7}{|c|}{ Phase 2: Exploration } \\
\hline \multicolumn{2}{|c|}{ IAE Well Permit } & \multirow{2}{*}{\multicolumn{2}{|c|}{ IAE Well Drilling }} & \multirow{2}{*}{\multicolumn{2}{|c|}{ IAE Well Rework }} & Total Phase II \\
\hline Application & Approval & & & & & cost \\
\hline \multicolumn{2}{|c|}{ CalGEM } & Start & Complete & Start & Complete & \\
\hline $3 / 20 / 2007$ & $3 / 28 / 2007$ & $10 / 16 / 2007$ & $12 / 7 / 2007$ & $3 / 9 / 2008$ & $3 / 26 / 2008$ & \\
\hline \multicolumn{2}{|c|}{$\$ 25,000$} & \multicolumn{2}{|c|}{$\$ 3,930,000$} & \multicolumn{2}{|c|}{$\$ 1,155,300$} & $\$ 10,500$ \\
\hline
\end{tabular}

In 2001, Layman Energy Associates (LEA) secured noncompetitive leasing rights in the area and conducted a geological assessment of the geothermal resources with a DOE grant. Layman Energy/Iceland America Energy jointly extended exploration and development activities with a grant from Geothermal Resources Development Account (GRDA). This effort culminated with a deep well 
drilling (IAE Truckhaven - 1). However, IAE pulled out of this project in 2011 and transferred all assets to Nevada Geothermal Power. The lease owners did not apply for an extension of existing leases, resulting in BLM terminating all leases and starting a new process for competitive leasing. In 2014, Ormat Technologies and its associates obtained the federal land lease for future exploration and development activities.

For this study, we collected timelines and expense data related to LEA/IAE efforts in TGLA. Figure 6 shows the timelines starting from land leasing application in 2001 to the closure of the land leases by BLM in 2011. Costs associated with various LEA/IAE exploration efforts are given in Table 6.

\section{Black Rock 1, 2, and 3, Salton Sea KGRA}

Black Rock 1, 2, and 3 Geothermal Power Project, in lieu of formerly Salton Sea Unit \# 6, involved geothermal development activities in the Salton Sea KGRA. An affiliate company of CalEnergy (Berkshire Hathaway Energy), CE Obsidian Energy, filed an application for certification (AFC) to CEC to establish a $185 \mathrm{MW}$ geothermal plant in July 29, 2002. With assistance from several responsible agencies, CEC led the effort to review the project, including resource viability for power generation and environmental review (Figure 7). CEC approved AFC for this project on December 17, 2003. In 2007, CEC approved an added binary-cycle system to the existing plan with an increase in capacity to $215 \mathrm{MW}$. CalEnergy requested to delay the construction by extending the deadline multiple times along with a change to the project name and design over time. Instead of a single large multi-flash geothermal power plant (Salton Sea Unit \#6), the amended project would have three separate single-flash power units (Black Rock 1, 2, and 3), each with a capacity of $53 \mathrm{MW}$. However, in 2017, CalEnergy requested to null the AFC and terminated the project. In our discussion with CalEnergy personnel, the reason for termination of this project was prevailing unfavorable market forces.

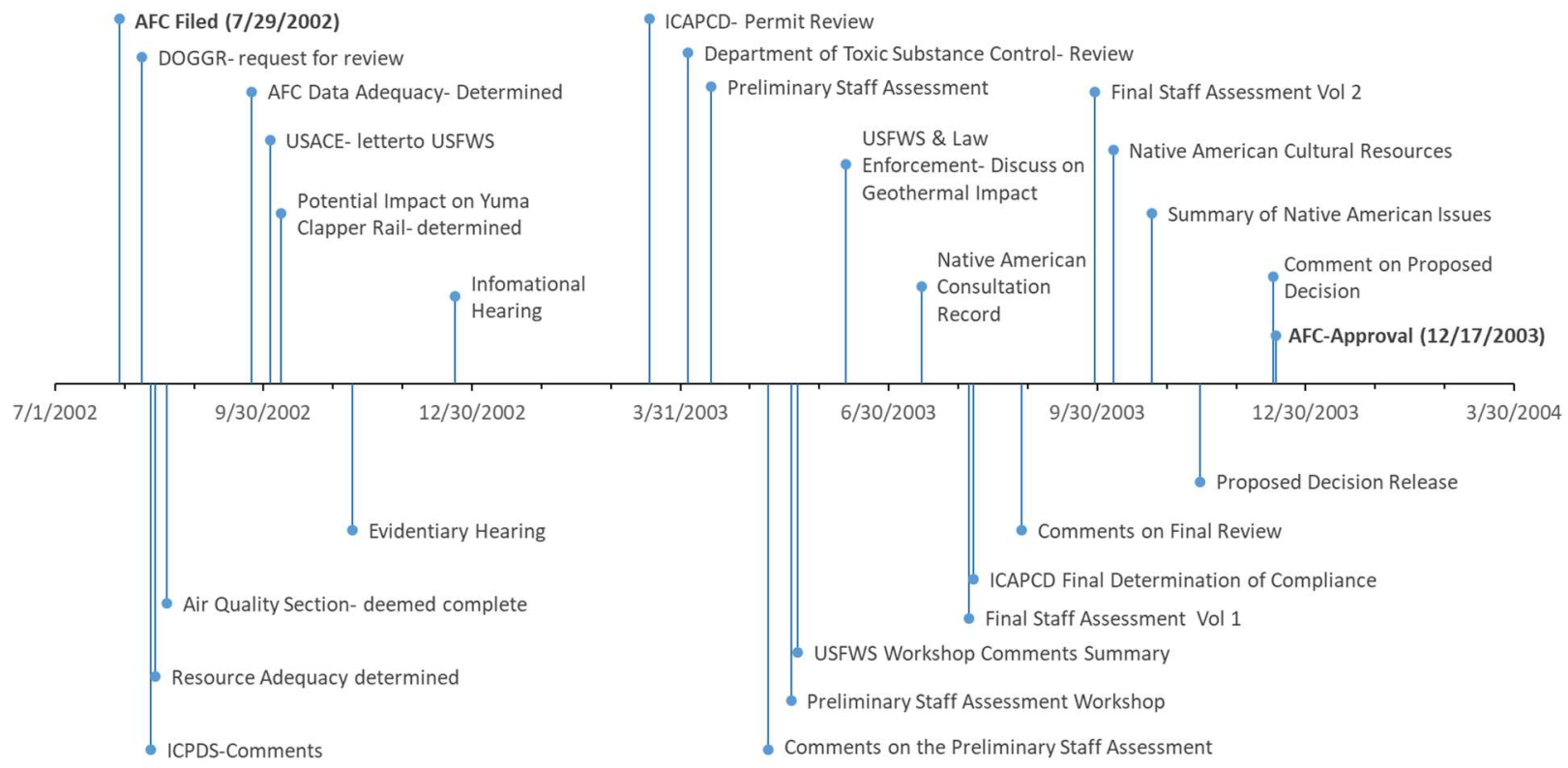

Figure 7. Timelines of CEC certification process for Blackrock 1-2-3 project in Salton Sea KGRA.

\section{Hell's Kitchen, Salton Sea KGRA}

Controlled Thermal Resource (CTR) is working to develop Hell's Kitchen geothermal power and lithium extraction project in Salton Sea KGRA. With multiphase development, CTR is planning to develop a 140 
MW geothermal power production facility and an extraction of $\sim 34,700$ tonnes/year lithium carbonate equivalent (LCE) with the potential to expand. In the first stage, however, CTR is aiming to produce 49.9 MW of power and 17,350 tonnes/year LCE. In June 2020, it signed a $40 \mathrm{MW}$ power purchase agreement (PPA) at \$69/MWh with Imperial Irrigation District (IID). Currently, it is in the process of getting approvals to develop well field, power plant, and a mineral extraction facility. According to IID Energy Consumers Advisory Committee' January 6, 2020, meeting minutes (IID, 2020), the CTR's leased area also covers a portion of the Salton Sea, which is defined as the Waters of the United States (WOTUS), a navigable body of water. With this designation, the permitting process requires CEQA, NEPA, and Section 404 of the CWA reviews and approval from local, state, and federal agencies. Section 404 of the CWA, specifically, requires the U.S. Army Corp of Engineers (USACE) to review the project for its potential impacts on WOTUS. If USACE anticipates the project to cause potential adverse impacts on existing environmental and biological resources, a mitigation plan must be developed before approving the permit for development.

The timeline of the ongoing permitting process of Hell's Kitchen project is shown in Figure 8. In summary, CTR applied and obtained CUP from ICPDS in 2017 for the exploration of geothermal resources and validated the viability of the geothermal resource for a possible future geothermal power plant. This CUP included the construction of up to four well pads for up to six exploratory wells on the land leased from IID. ICPDS approved this CUP with conditions as an addendum to the Imperial County's Programmatic Final EIR, Renewable Energy \& Transmission Element (SCH\# \# 2014071062) prepared in 2015. The stipulated conditions in the CUP approval are the receipt of approvals from other agencies (e.g., CDFW and USACE). Recently, IID wrote a letter to President Biden to expedite CTR's federal permitting applications. Based on the available data and information obtained through interviews with CTR and USACE, the delays in permitting for this ongoing project could be traced to the lack of consensus among developers, state agencies, and federal agencies on mitigation measures needed at or nearby the project site to minimize or compensate the potential impact the project would cause to the WOTUS and its environmental and biological resources.

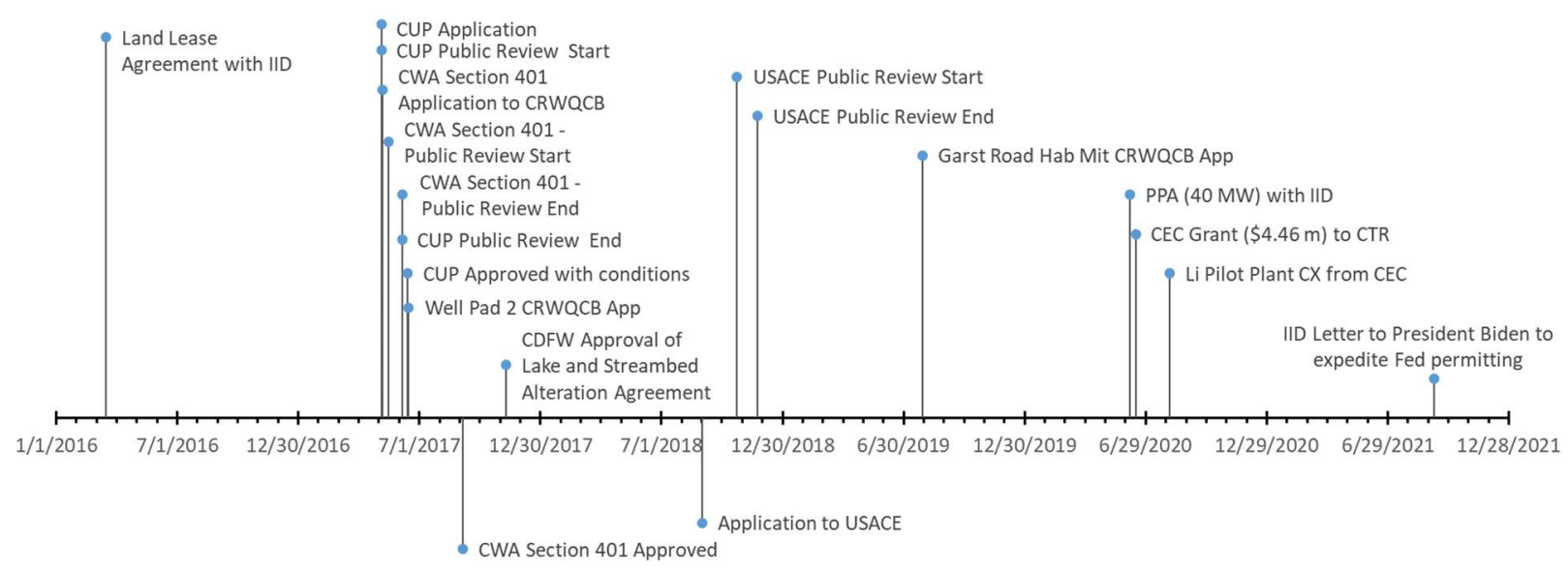

Figure 8. Timelines of ongoing permitting reviews of CTR's Hell's Kitchen project.

\section{Selected Study Sites in Churchill County, Nevada}

Churchill County in Nevada has several existing geothermal power plants scattered in six KGRAs. Also, this county has several geothermal projects currently seeking regulatory permitting for exploration and development activities. Figure 9 shows the locations of KGRAs in Churchill as well as neighboring 
Washoe County. For this study, we selected four geothermal development activities, two geothermal projects from the Salt Wells KGRA and two projects from the Dixie Valley KGRA, in Churchill County.

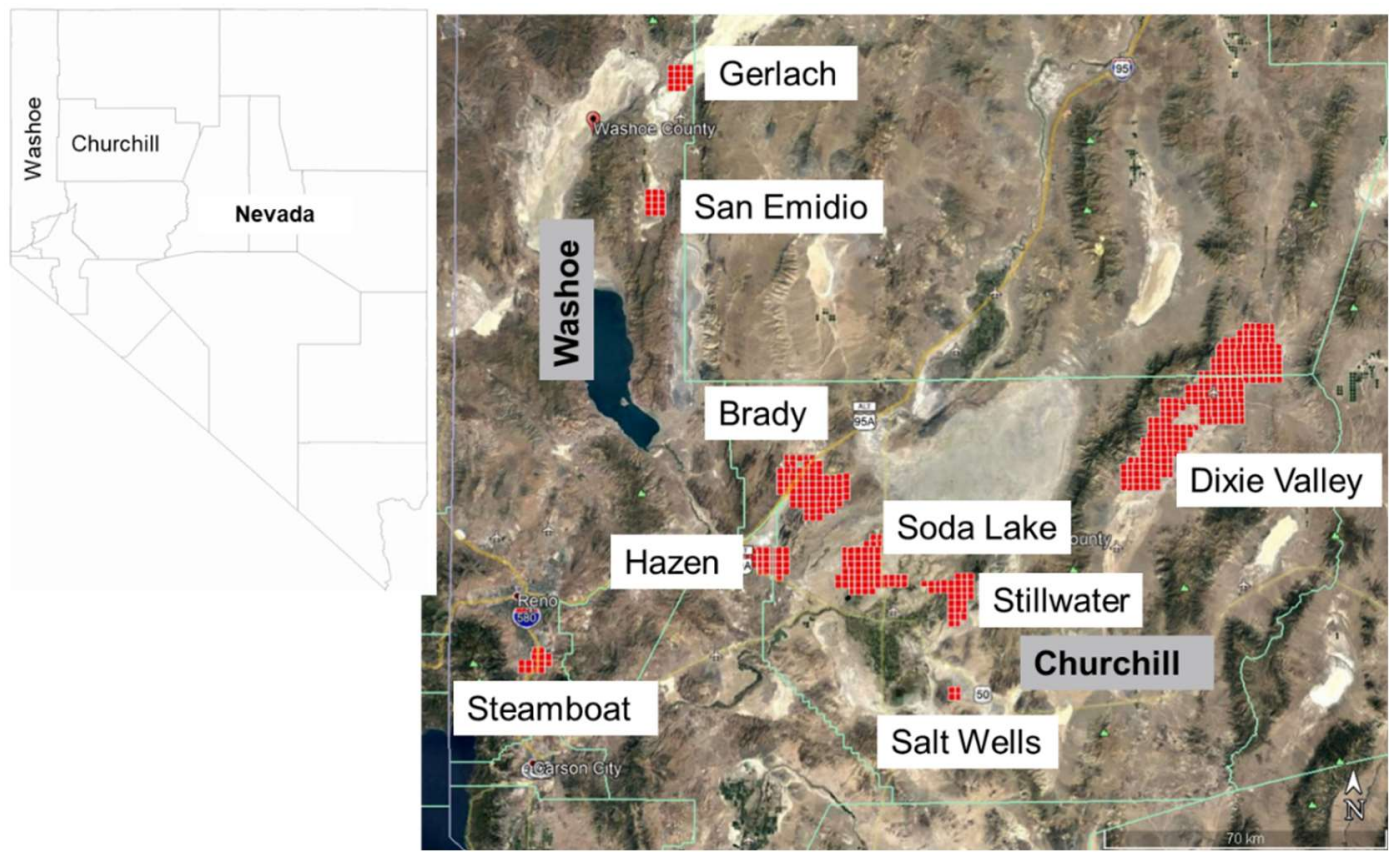

Figure 9. Locations of KGRAs in Churchill and Washoe Counties, NV. Geothermal sites in Salt Wells and Dixie Valley KGRAs are selected for this study.

\section{Salt Wells, Enel North America}

Since 2009, Enel North America has operated a geothermal power plant (23.6 MW) in Salt Wells KGRA. For the development of currently operating power plants, leasing and exploration activities were originally started by Nevada Geothermal Specialists (NGS) in 2003. Once NGS leased land from BLM in 2003, they proceeded to obtain permits for exploration and drilling in 2004. However, Amp Resources acquired NGS assets, including land leases, and proceeded with applications for the development of a well field and power plant. Again in 2006, after Amp started to construct the power plant, all its assets were transferred to Enel North America. Eventually, Enel completed construction of the power plant in 2009. The detailed timeline of this project is given in Figure 10. Available (and assumed) cost data associated with various permitting and development activities are given in Table 7. 


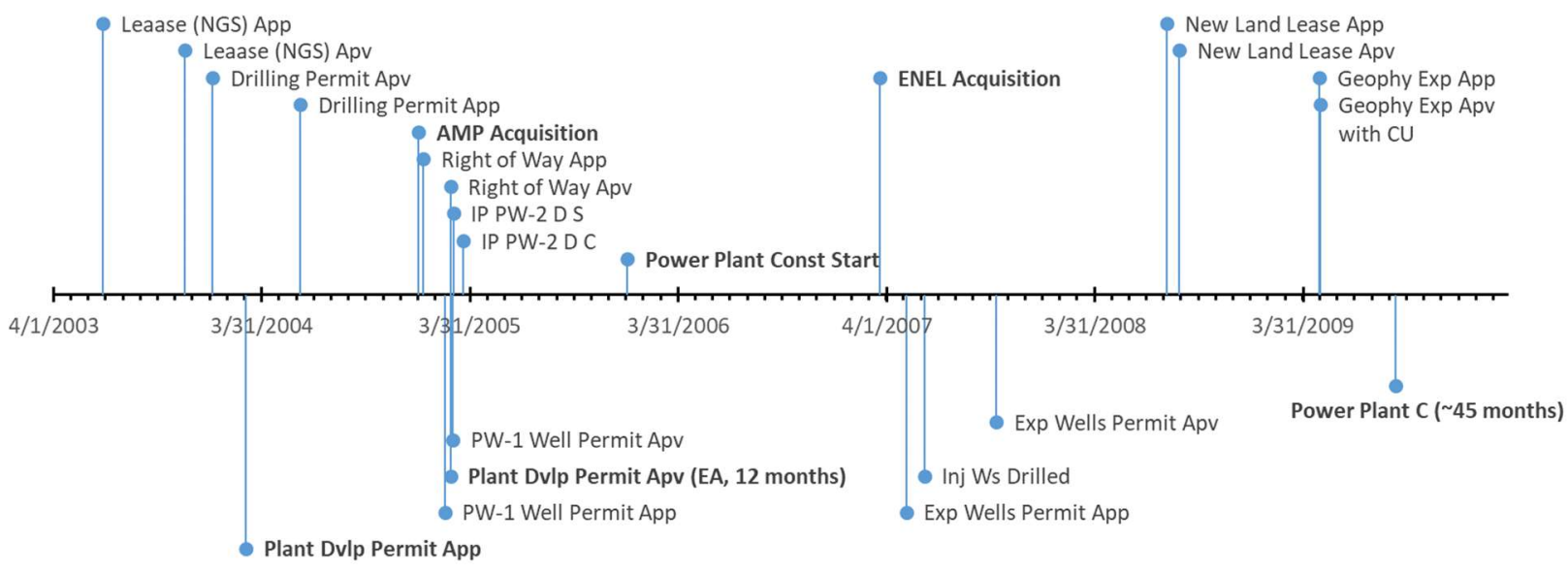

Figure 10. Permitting and development timelines of Enel's Salt Wells geothermal power plant.

Table 7. Timelines and approximate costs of Enel's Salt Wells geothermal power plant.

\begin{tabular}{|c|c|c|c|c|c|c|c|c|}
\hline Steps & \multicolumn{2}{|c|}{ Lease (NGS) } & \multicolumn{2}{|c|}{ Drilling Permit } & AMP & \multicolumn{3}{|c|}{ EA Plant Development } \\
\hline Action & Application & Approval & Application & Approval & Acquired & Application & \multicolumn{2}{|c|}{ Approval } \\
\hline Dates & $6 / 26 / 2003$ & $11 / 17 / 2003$ & $1 / 5 / 2004$ & $6 / 6 / 2004$ & $12 / 31 / 2004$ & $3 / 3 / 2004$ & \multicolumn{2}{|c|}{$2 / 25 / 2005$} \\
\hline Approx Cost & \multicolumn{2}{|c|}{$\$ 69,771^{1}$} & \multicolumn{2}{|c|}{$\$ 50,000^{2}$} & & \multicolumn{3}{|c|}{$\$ 11,250^{3}$} \\
\hline Steps & \multicolumn{2}{|c|}{ Right of Way } & \multicolumn{2}{|c|}{ PW-1 Permit } & \multicolumn{2}{|c|}{ IP PW-2 } & \multicolumn{2}{|c|}{ Power Plant } \\
\hline Action & Application & Approval & Application & Approval & Start & Completion & \multicolumn{2}{|c|}{ Start } \\
\hline Dates & $1 / 8 / 2005$ & $2 / 25 / 2005$ & $2 / 15 / 2005$ & $3 / 1 / 2005$ & $3 / 2 / 2005$ & $3 / 19 / 2005$ & \multicolumn{2}{|c|}{$1 / 1 / 2006$} \\
\hline Approx Cost & \multicolumn{2}{|c|}{$\$ 4,000^{2}$} & & & & & & \\
\hline Steps & ENEL & $\begin{array}{c}\text { Expl Wells } \\
\text { Permit }\end{array}$ & $\begin{array}{l}\text { Inj Ws } \\
\text { Drilled }\end{array}$ & \multicolumn{2}{|c|}{ New Land Lease } & \multicolumn{2}{|c|}{ CU Geophy Exploration } & Power Plant \\
\hline Action & Acquired & Approved & Completion & Application & Approved & Application & Approval & Completion \\
\hline Dates & $3 / 20 / 2007$ & $10 / 10 / 2007$ & $6 / 6 / 2007$ & $8 / 5 / 2008$ & $8 / 26 / 2008$ & $4 / 29 / 2009$ & $4 / 30 / 2009$ & $9 / 9 / 2009$ \\
\hline Approx Cost & & & & \multicolumn{2}{|c|}{$\$ 2,707,140^{1}$} & \multicolumn{2}{|c|}{$\$ 1,500$} & $\$ 126,000,000^{4}$ \\
\hline
\end{tabular}

1. Application plus lease bonus bids, 2. Well bond, 3. Estimated value, 4. Enel's Salt Wells well field plus plant cost was not found. This figure is the cost for Enel's similar sized plant in Cove Fort - I, UT.

\section{Salt Wells, Ormat}

Ormat Technologies acquired the geothermal lease in 2006 and started geothermal exploration in the area (Figure 11). BLM's Carson City Field Office, in Nevada, conducted the NEPA review for exploratory geothermal drilling in 2007 to 2008 with an EA/FONSI. Later in 2009, Ormat submitted a plan to utilize the geothermal resources to BLM. In the same area, Ormat, along with two other companies-Vulcan Power Company and Sierra Pacific Power Company-applied for the geothermal utilization and right-ofway application for transmission lines in the Salt Wells KGRA. BLM completed NEPA review of these three projects with a combined EIS in 2011. 


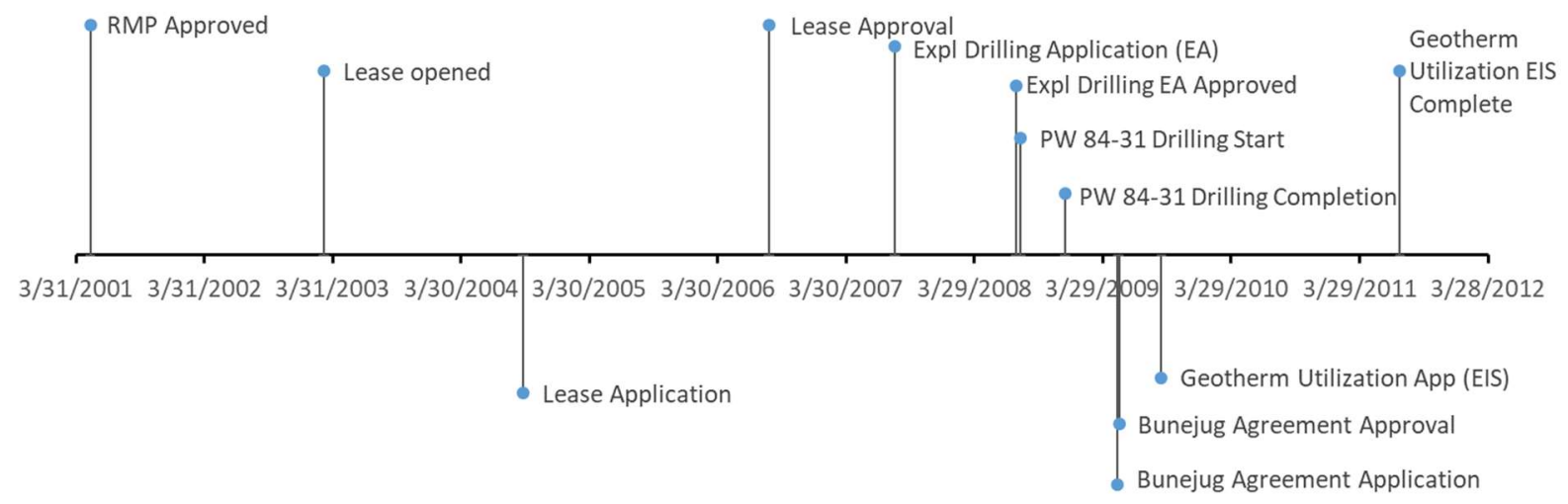

Figure 11. Permitting and exploration timelines of Ormat's Salt Wells geothermal site.

\section{Dixie Meadows, Ormat}

Since 2007, Ormat Technologies (through its subsidiary Orni 32, LLC) has engaged in the exploration and development of geothermal resources in Dixie Valley's Dixie Meadows Geothermal Unit Area. This project includes BLM lands as well as U.S. Navy's Lamb Mineral Interests lands. The detail timelines of the lease/permitting and exploration activities in the area are given in Table 8. Early geophysical exploration activities in the area only required an NOI/CX level of environmental reviews. BLM completed two EAs in 2010 and 2011 for lands within Ormat leases in the Dixie Meadows area and in the Dixie Hope geothermal prospect, which was originally leased to Terra-Gen (and later acquired by Ormat). The first EA (completed in 2010) was for exploration by drilling and testing on Dixie Hope project's land, which also included some parcels of the Dixie Meadows area under Terra-Gen's lease. The second EA (NEPA review timeline presented in Figure 12) was for exploration by drilling and testing on the pre-Terra-Gen acquisition Ormat leased lands. These two EAs permitted up to 34 well pads, 205.6 acres of surface disturbance on BLM lands, and 4 acres of surface disturbance on land with the U.S. Navy's Lamb Mineral Interests. In 2015, Ormat submitted a utilization plan in the area. BLM initiated a NEPA review and completed an EA draft in 2017. During public review, BLM received comments from various stakeholders (Table A3), including federal and state agencies, tribes, environmental justice groups, and private citizens. Many environmental justice groups and private citizens raised concerns related to the protection of the newly discovered Dixie Valley Toad species whose unique habitat depends on the discharge from the naturally existing hot springs in the area. A petition was filed by Center for Biological Diversity to list the Dixie Valley Toad as threatened or endangered species under the Endangered Species Act. The petition and other concerns made BLM and Ormat prepare and publish an Aquatic Resources Monitoring and Mitigation Plan (ARMMP) and re-issued a new EA draft with FONSI on 13 January 2021 (Figure 14) with a comment period ending on 12 February 2021. BLM received many new public comments from federal, state, local agencies, a tribal group, and Center for Biological Diversity (Table A2). New public comments were used to further modify the EA and ARMMP with the identification of a framework for adaptive management actions and mitigation measures based on monitoring results. On 23 November 2021, the final EA for Dixie Meadows Development Project was approved by BLM with a FONSI. 
Table 8. Permitting and exploration timelines of Ormat's Dixie Meadows Geothermal Site.

\begin{tabular}{|c|c|c|c|c|c|c|c|c|c|c|c|}
\hline Steps & \multicolumn{2}{|c|}{ Lease (1996) } & \multirow{2}{*}{\begin{tabular}{|l|} 
LUP \\
Approved
\end{tabular}} & \multicolumn{2}{|c|}{ Lease (2007) } & \multicolumn{2}{|c|}{ Lease (2009) } & \multicolumn{2}{|c|}{ Seismic/EM Survey - CX } & \multicolumn{2}{|c|}{ Drilling \& Testing EA } \\
\hline Actions & Application & Approval & & Application & Approval & Application & Approval & Application & Approval & Application & Approval \\
\hline Dates & $3 / 6 / 1996$ & $6 / 18 / 1996$ & $5 / 9 / 2001$ & $8 / 14 / 2007$ & $9 / 10 / 2007$ & $7 / 14 / 2009$ & $8 / 7 / 2009$ & $6 / 30 / 2009$ & $1 / 21 / 2010$ & $9 / 15 / 2009$ & $6 / 7 / 2010$ \\
\hline $\begin{array}{c}\text { Timelines } \\
\text { (month) }\end{array}$ & \multicolumn{2}{|c|}{3.5} & & \multicolumn{2}{|c|}{0.9} & \multicolumn{2}{|c|}{0.8} & \multicolumn{2}{|c|}{6.8} & \multicolumn{2}{|c|}{8.8} \\
\hline Cost & \multicolumn{2}{|c|}{$\$ 21,800$} & & \multicolumn{2}{|c|}{$\$ 1,806,975$} & \multicolumn{2}{|c|}{$\$ 11,496$} & & \\
\hline Steps & \multicolumn{2}{|c|}{ ROW Access Road } & $\begin{array}{c}\text { Acquisition } \\
\text { of TGP }\end{array}$ & \multicolumn{2}{|c|}{ Drilling \& Testing EA ${ }^{1}$} & \multicolumn{2}{|c|}{$\begin{array}{c}\text { Dixie Meadows } \\
\text { Geothermal Agmt }\end{array}$} & \multicolumn{2}{|c|}{ TG Well - CX } & Well 22-8B & $\begin{array}{c}\text { Well 22D- } \\
8 \\
\end{array}$ \\
\hline Actions & Application & Approval & Signed & Application & Approval & Application & Approval & Application & Approval & Drilled & Drilled \\
\hline Dates & $10 / 15 / 2009$ & $6 / 7 / 2010$ & $12 / 30 / 2010$ & $3 / 15 / 2011$ & $1 / 17 / 2012$ & $1 / 30 / 2012$ & $2 / 1 / 2012$ & $5 / 16 / 2012$ & $6 / 18 / 2012$ & 2012 & 2012 \\
\hline $\begin{array}{c}\text { Timelines } \\
\text { (month) }\end{array}$ & \multicolumn{2}{|c|}{7.8} & & \multicolumn{2}{|c|}{10.3} & \multicolumn{2}{|c|}{0.1} & \multicolumn{2}{|c|}{1.1} & & \\
\hline \multicolumn{12}{|l|}{ Cost } \\
\hline Steps & Well 23-8 & Well 23A-8 & Well 24A-8 & $\begin{array}{c}\text { Well } \\
\text { 24(13)-8ST2 }\end{array}$ & \multicolumn{2}{|c|}{$\begin{array}{c}\text { Drilling/ROW Access Road- } \\
\text { DNA }\end{array}$} & \multicolumn{2}{|c|}{ TG Well-DNA } & \multicolumn{3}{|c|}{ Lease (2013a) } \\
\hline Actions & Drilled & Drilled & Drilled & Drilled & Application & Approval & Application & Approval & Application & \multicolumn{2}{|c|}{ Approval } \\
\hline Dates & 2012 & 2016 & 2016 & 2017 & $6 / 11 / 2012$ & $11 / 30 / 2012$ & $1 / 18 / 2013$ & $2 / 14 / 2013$ & $1 / 29 / 2013$ & \multicolumn{2}{|c|}{$2 / 26 / 2013$} \\
\hline $\begin{array}{c}\text { Timelines } \\
\text { (month) }\end{array}$ & & & & & \multicolumn{2}{|c|}{5.7} & \multicolumn{2}{|c|}{0.9} & \multicolumn{3}{|c|}{0.9} \\
\hline Cost & & & & & & & & & & $\$ 320$ & \\
\hline Steps & Lease & (2013b) & Lease & (2014) & Expans & on Agmt & Utilizat & ion-EA ${ }^{2}$ & PPA & SUP Ch & urchill \\
\hline Actions & Application & Approval & Application & Approval & Application & Approved & Application & Approval & Signed & Application & Approval \\
\hline Dates & $11 / 19 / 2013$ & $11 / 22 / 2013$ & $9 / 10 / 2014$ & $11 / 3 / 2014$ & $9 / 1 / 2016$ & $12 / 22 / 2016$ & $12 / 3 / 2015$ & $11 / 23 / 2021$ & $10 / 20 / 2016$ & $6 / 4 / 2020$ & Pending \\
\hline $\begin{array}{l}\text { Timeline } \\
\text { (month) }\end{array}$ & & 1 & & .8 & & .7 & 72 & .7 & & 17. & \\
\hline Cost & $\$ 1$ & 040 & & 80 & & & & & & & \\
\hline
\end{tabular}

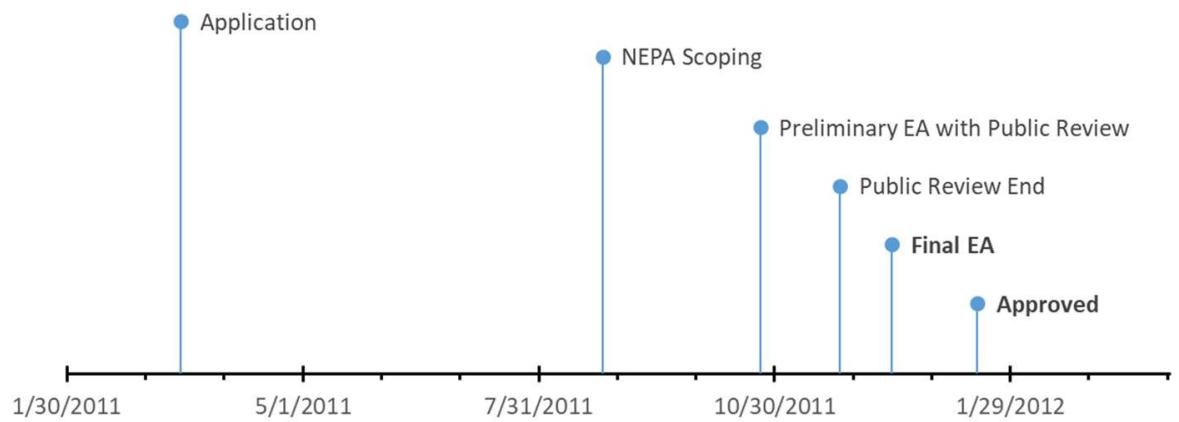

Figure 12. NEPA review timelines for drilling and testing (blue box in Table 8) on land leased to Ormat for Dixie Meadows Geothermal Project.

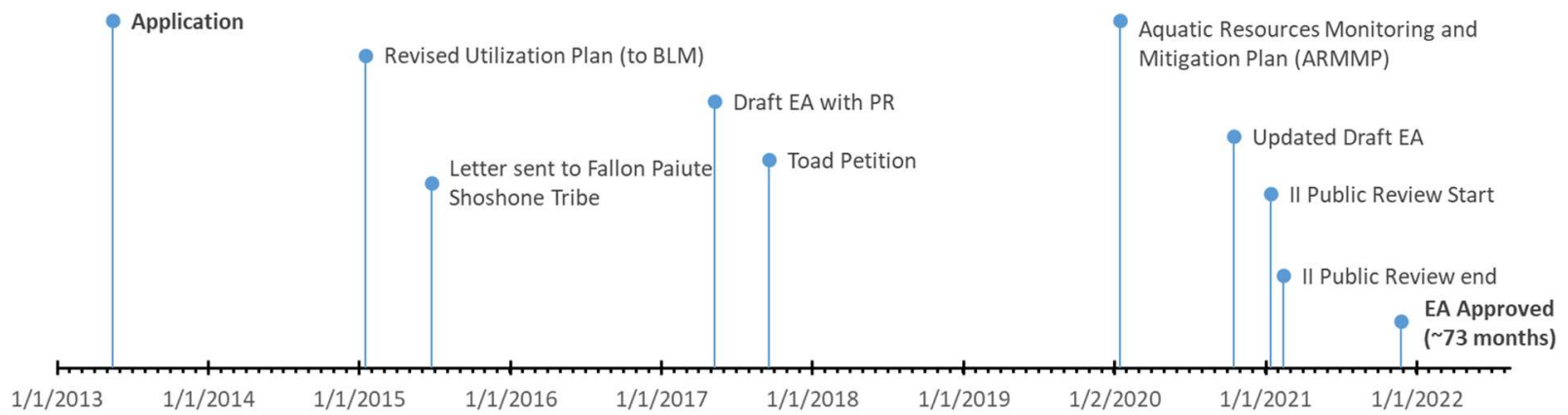

Figure 13. NEPA review timelines for developing utilization facilities (red box in Table 8) on land leased to Ormat for Dixie Meadows Geothermal Project. The approval of final EA is still pending. 


\section{Selected Study Sites in Beaver County, Utah}

Beaver County in Utah has three KGRAs (Figure 14), each hosting operational geothermal facilities. The Roosevelt Hot Springs KGRA has supported the Blundell Geothermal Plant (PacifiCorp) since 1984.

Adjacent to this facility is the site of DOE-funded Frontier Observatory for Research in Geothermal Energy (FORGE). Sulphurdale/Cove Fort KGRA has also been producing power since 1984. The Thermo Hot Springs KGRA started operation of Thermo 1 power plant in 2012, mostly on private and state lands. Because of the availability of data and nature of land ownership, we selected Cove Fort - I and Cove Fort - II geothermal projects as examples to evaluate the impact of permit timelines on geothermal development in Utah.

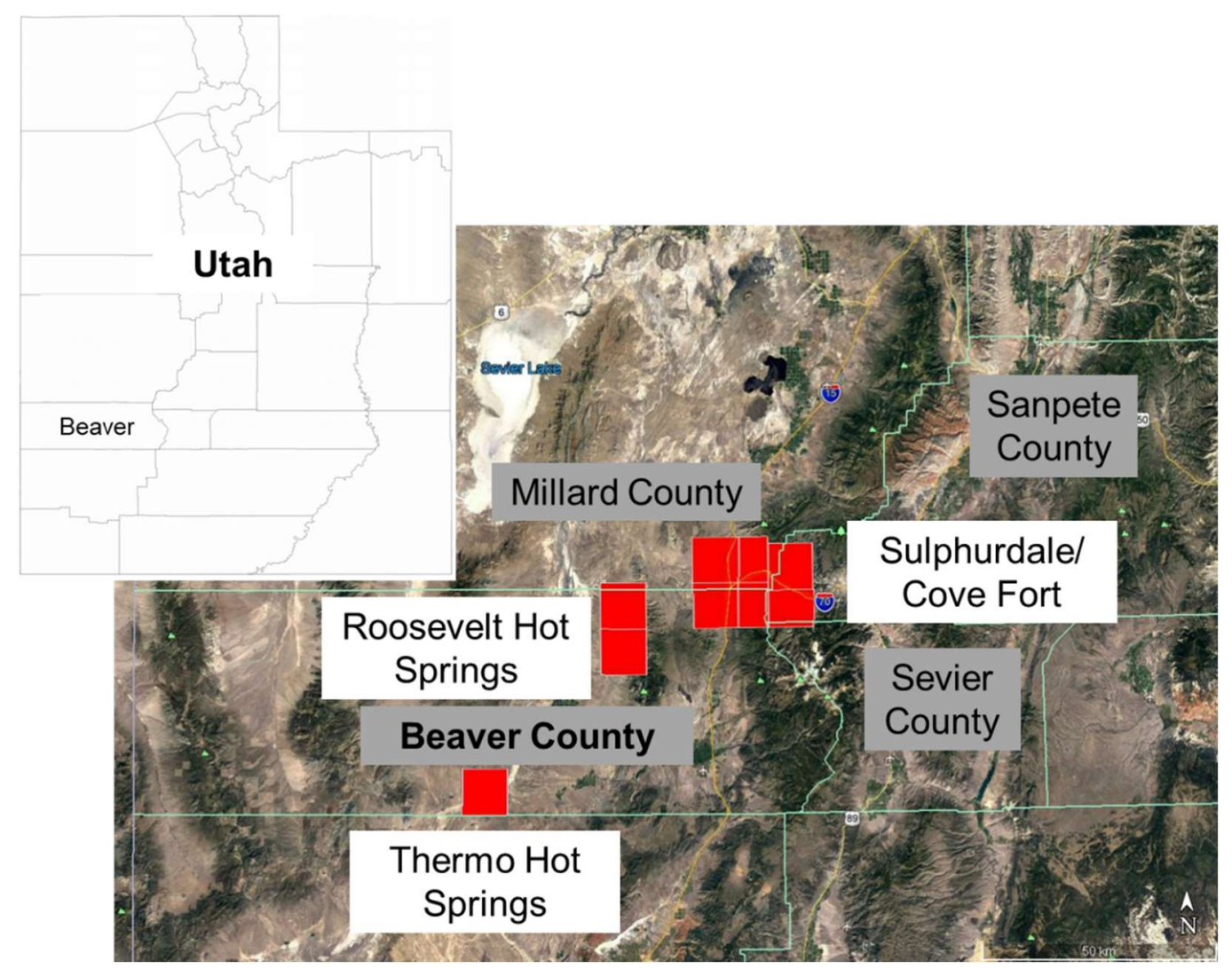

Figure 14. Locations of KGRAs in Beaver and surrounding counties in Utah.

\section{Cove Fort - I and Cove Fort - II}

Systematic geothermal activities in Sulphurdale/Cove Fort KGRA began with the initial land lease issued to Unocal in 1975 and subsequent exploration and development of a 2.6 MW binary-cycle plant (Bud L Bonnett Plant - A, BLB - A) in 1984. Within a few years, BLM and U.S. Forest Service issued a programmatic Resource Management Plan (RMP) and Land Management Plan (LMP) EIS in 1986 that analyzed the environmental issues with the geothermal development. The area witnessed two additional Unocal geothermal production plants (2MW BLB - B established in 1986 and 8.5 MW BLB - C established in 1990). BLM expanded the geothermal leasing area and completed the NEPA review with a Leasing EA in 2006. In 2007, Enel North America purchased the BLP - C plant and other assets in the area as well as acquired additional land leases from BLM. Enel demolished the existing power plant and started a new phase of developmental activities. The timeline of Enel's activities in the area is shown in 
Figure 15. In summary, Enel applied for a new resource utilization plan to BLM, Beaver County, and Millard County (UT). BLM conducted a NEPA review for the new utilization plan with an EA in 2012. Both counties approved CUP in 2012. The construction of a new geothermal plant (25 MW) began in 2012 and was completed in 2013.

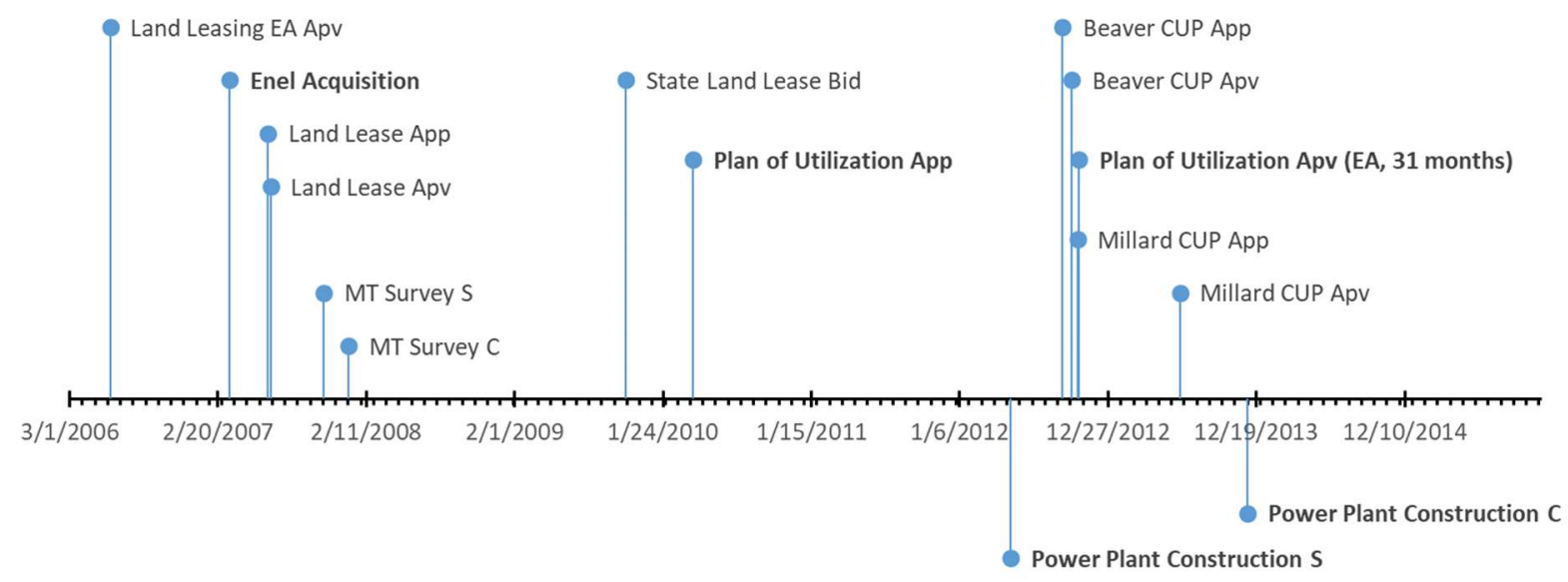

Figure 15. Timeline of Enel's activities for development of Cove Fort - I geothermal plant.

After the completion of Cove Fort - I, Enel moved ahead to expand the power production in the area. The company applied for building Cove Fort - II to BLM in 2014. BLM conducted a NEPA analysis and documented the environmental review as an EA in 2016. Based on this NEPA analysis, BLM approved EA with FONSI on 9 September 2016. However, the Cove Fort - II has yet to be built in the area.

\section{Techno-economic Analysis}

A TEA tool using Microsoft Excel was prepared and applied for this study. Several assumptions were considered for the TEA. We assumed the duration of plant operation to be 30 years. The discount rate on the capital equipment is assumed as $6 \%$ annually. Capacity factor of $70 \%$ is assumed. In addition to the actual geothermal sites, a hypothetical geothermal site in the Salton Sea KGRA is considered with multiple environmental review scenarios, which resulted in different project development timelines.

\section{Simplified LCOE for Different Sites}

Simplified LCOE values were calculated for four sites. These are Salt Wells-Enel, Cove Fort - I, Hudson Ranch - I, and Hudson Ranch - II. Project specific available cost data, such as leasing costs (bonus bids), lease rental costs, permitting costs, and other exploration-development related costs, were used to calculate the sLCOE. For each site, the cost data were adjusted to the year of power plant completion by applying a constant annual interest rate of $6 \%$, assuming those costs were financed. For each site, the costs, timelines, and sLCOE calculations are given in the supporting Excel files. It is important to note that these power plants have different rated production capacities, permitting requirements, and timelines. Given the wide range of site-specific variables, it is likely that some itemized costs for each project site considered could not be captured. It is expected that any uncaptured itemized costs would be small in proportion to the overall project costs and would have little impact on SLCOE.

The Salt Wells-Enel is producing electricity at the lowest rate with sLCOE of $\$ 53.8 / \mathrm{MWh}$ (in 2009). The calculated sLCOE for the Cove Fort-I plant is $\$ 69.7 / \mathrm{MWh}$ (2013). This value is slightly less than the PPA of $\$ 79 / \mathrm{MWh}$ that Enel North America signed for this power plant with Salt River Project. However, the 
signed PPA was for 20 years, and the value shown in Figure 16 is calculated based on a 30-year operational period. With a 20 -year operation, we would get SLCOE of about $\$ 82 / \mathrm{MWh}$ in our calculation. Given the quality of data used for this study, the value of calculated sLCOE is consistent with the Enel's PPA with Salt River Project.

Both the Hudson Ranch geothermal plants resulted in a sLCOE higher than the national average electricity price. [Note: Hudson Ranch-II was never built. The calculation is based on the permitting cost data and timelines of this project with the plant, well field, and transmission costs of Hudson Ranch -I]. The costlier electricity from these plants reflect higher development costs in the Salton Sea KGRA because both the plant and the well field have to be designed for handling highly corrosive brines.

We also calculated the LCOE using GETEM (Mines, 2008; 2016). Default values were used for all parameters except the site-specific resource temperature, depth to the reservoir, and power-technology (e.g., flash or binary). GETEM-provided LCOE values (Figure B3) are also lower for Salt Wells and Cove Fort-I and higher for both Hudson Ranch projects. However, LCOE value with GETEM for each site is relatively higher compared to SLCOE values (Figure 16). The higher discount rate (7\%) and higher derived rate for fixed cost ( $0.02-0.03 / \mathrm{KWh})$ contributed to higher LCOE with GETEM.

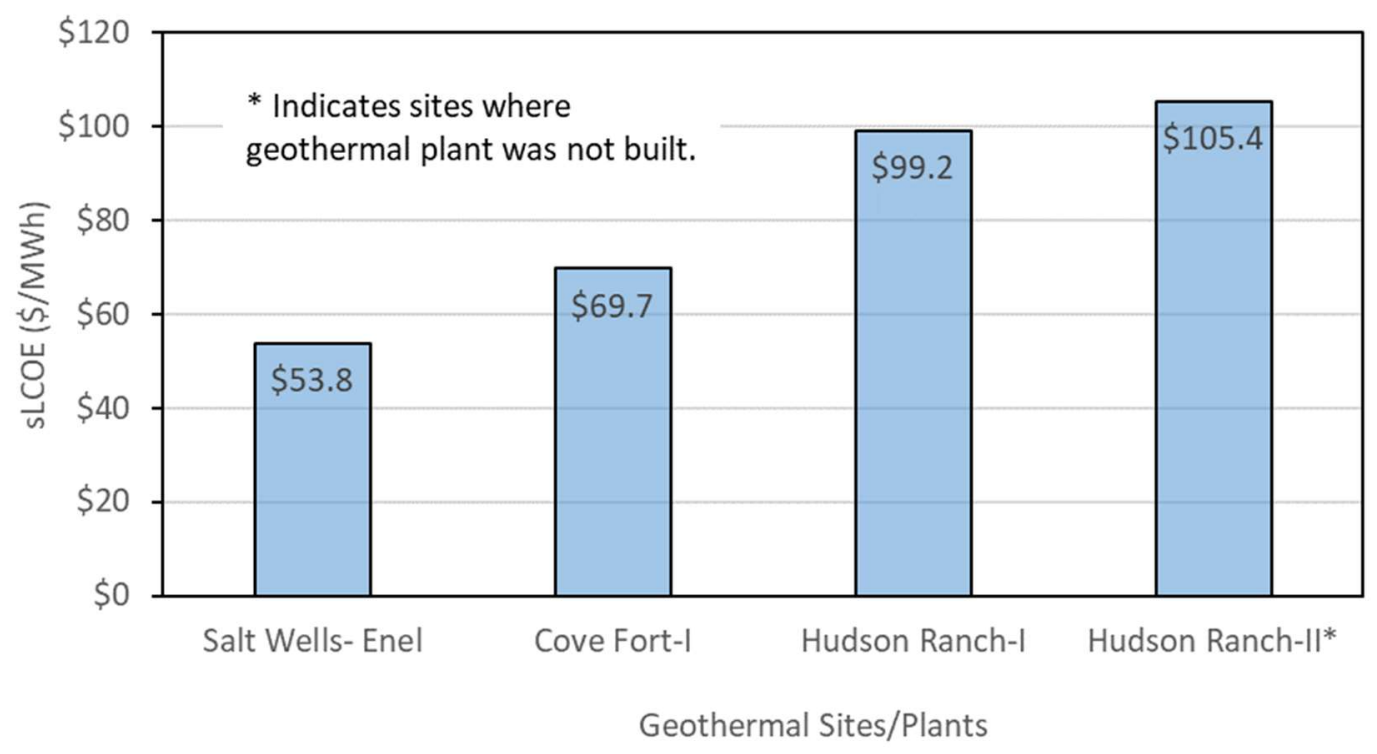

Figure 16. Summary of sLCOE at different

\section{TEA Sensitivity on Permitting Timeline}

We tested TEA sensitivity on permitting timeline by creating several environmental management and permitting scenarios applied to a hypothetical geothermal power plant development in the Salton Sea KGRA. Assuming a fixed operation time of 30 years for the power plant, we varied the time required for permitting, exploration, and development. Both the sLCOE and gained or lost revenues were calculated to assess the impact of different permitting and development timelines.

The hypothetical project is designed to have various stages with the potential for different environmental modeling scenarios and degrees of complexity in the CEQA/NEPA review process. Specifically, these scenarios are consistent with the environmental management scenarios given in Table 1. As stated above, these scenarios mostly mimic the CEQA/NEPA review process that occurred or are 
occurring to one or many of the geothermal development activities in Imperial County. The Scenario $E$ in Table 1 is not considered for the hypothetical case since the geothermal resource area around the Salton Sea is a designated KGRA (Imperial County, 1982). The Imperial County has also developed a Master EIR for the geothermal development in the Salton Sea KGRA in 1981 (Imperial County, 1981), and the county periodically updates its Renewable Energy \& Transmission Element EIR (e.g., ICPDS, 2015). The hypothetical project facilitated generation of a complete set of synthetic costs and timeline data for various stages of the project and assess the impact of permitting timelines on the sLCOE. Different stages of this hypothetical project and CEQA/NEPA review scenarios are given below.

1. The developers secured a 30-year lease for 1000 acres of land from IID in 2010. The terms of the lease are similar to the land lease terms that CTR had with IID in 2020. Specifically, the lease term includes a rate of $\$ 20 /$ year/acre during the exploration phase. After the resource was determined viable, the lease amount would increase to $\$ 100 /$ year/acre for 950 acres and $\$ 600 /$ year/acre for 50 acres of land occupied by the well field and power plant. Developers also secured access to industrial water from IID. To allow us to make various environmental scenarios and permitting timelines and test their impact on LCOE, the actual project would sit in two potential locations within the leased land. In one case, the well field and plant would sit outside of the Salton Sea playa that only requires minor improvements in the road for access. Well pads, wells, and plant facility would be built on deeply disturbed farmland. The second potential site would be located outside the playa but may require access to the playa or even sit well pads on the playa. If there is a need to access land or playa below $-231 \mathrm{ft}$ elevation, it also requires both NEPA and CWA Section 404 reviews and permitting from USACE.

2. Despite the site being within KGRA, the developers chose to assess the resource viability at the project site for a future $49.9 \mathrm{MW}$ plant.

3. They applied CUP for exploration by drilling and testing. The timeline of the CUP and other regulatory permits varies with the location and various environment management scenarios. Eventually, all permitting requirements were completed with different timelines for different scenarios (Table 1 and Table 9).

Table 9. Permitting, exploration, and development timelines for a hypothetical geothermal project in Salton Sea KGRA.

\begin{tabular}{|c|c|c|c|c|c|c|c|c|c|c|}
\hline \multirow{5}{*}{$\begin{array}{c}\text { IID Land } \\
\text { Leased }\end{array}$} & \multicolumn{10}{|c|}{ Exploration by drilling wells and testing } \\
\hline & \multirow{2}{*}{\multicolumn{2}{|c|}{ CUPICPDS }} & \multicolumn{8}{|c|}{ Ancillary Permitting } \\
\hline & & & \multirow{3}{*}{\multicolumn{2}{|c|}{$\frac{\text { Scenario-A }}{\text { None }}$}} & \multicolumn{2}{|c|}{ Scenario-B } & \multicolumn{2}{|c|}{ Scenario-C } & \multicolumn{2}{|c|}{ Scenario-D } \\
\hline & Applied & Approved-MND & & & Applied & Approved & Applied & Approved & Applied & Approved \\
\hline & $7 / 7 / 2010$ & $12 / 8 / 2010$ & & & $7 / 15 / 2010$ & $8 / 15 / 2011$ & $7 / 15 / 2010$ & $4 / 15 / 2013$ & $7 / 15 / 2010$ & $10 / 15 / 2015$ \\
\hline \multirow{2}{*}{\multicolumn{3}{|c|}{ Well Drilling and Testing ( 4 wells) }} & Start & End & Start & End & Start & End & Start & End \\
\hline & & & $12 / 15 / 2010$ & $7 / 8 / 2011$ & $10 / 15 / 2011$ & $12 / 15 / 2012$ & $6 / 15 / 2013$ & $10 / 15 / 2014$ & $12 / 15 / 2015$ & $6 / 15 / 2016$ \\
\hline \multicolumn{11}{|c|}{ Utilization } \\
\hline \multirow{2}{*}{\multicolumn{3}{|c|}{ CUPICPDS }} & Applied & Approved-EIR & Applied & Approved- EIR & Applied & Approved- EIR & Applied & Approved- EIR \\
\hline & & & $7 / 20 / 2011$ & $2 / 15 / 2012$ & $2 / 15 / 2012$ & $10 / 15 / 2014$ & $12 / 15 / 2014$ & $7 / 15 / 2016$ & $8 / 15 / 2016$ & $4 / 15 / 2018$ \\
\hline \multirow{2}{*}{\multicolumn{3}{|c|}{ Ancilliary Permits }} & \multirow{2}{*}{\multicolumn{2}{|c|}{ None }} & Applied & Approved & Applied & Approved & Applied & Approved \\
\hline & & & & & $2 / 15 / 2012$ & $10 / 15 / 2014$ & $12 / 15 / 2014$ & $10 / 15 / 2016$ & $8 / 15 / 2016$ & $8 / 12 / 2019$ \\
\hline \multirow{2}{*}{\multicolumn{3}{|c|}{$\begin{array}{c}\text { Production/Injection wells, Power Plant, and } \\
\text { Transmission lines }\end{array}$}} & Start & End & Start & End & Start & End & Start & End \\
\hline & & & $4 / 15 / 2012$ & $4 / 15 / 2016$ & $12 / 15 / 2014$ & $12 / 15 / 2018$ & $12 / 15 / 2015$ & $12 / 15 / 2019$ & $10 / 12 / 2019$ & $10 / 12 / 2023$ \\
\hline
\end{tabular}

4. The project moved ahead with drilling (4 wells) and testing for resource viability. After little over a year-long effort (in each scenario), the project determined the presence of adequate resources to sustain operation of a $49.9 \mathrm{MW}$ plant. 
5. Developers applied to ICPDS for resource utilization CUP. They also applied to obtain other permitting requirements to various agencies. Various environmental management scenarios were considered again for CUP and other permits that resulted in different permitting timelines.

6. Once all permitting requirements were met, developers were successful in building the power plant with a capital cost similar to Hudson Ranch - I.

Timelines of this hypothetical project starting from the land lease agreement to the commencement of the power plant are given in Table 9 with various CEQA and NEPA review scenarios. Scenarios $A$ through $D$ in Table 9 are consistent with Scenarios A through D in Table 1. For Scenarios A and B, the permitting timelines are similar to timeline structures of Hudson Ranch - I and Hudson Ranch - II. However, there are some variations, such as for Hudson Ranch - II, EnergySource directly applied for resource utilization CUP with an expectation that the resource is viable. Scenarios $C$ and $D$ also mimic the ongoing CEQA/NEPA review process of CTR's Hell's Kitchen project; however, there are some exceptions, such as the permitting process of this hypothetical project in both scenarios ( $C$ and $D$ ) obtained all required permits, and CTR is still uncertain when it will be able to obtain permitting approvals from federal agencies. In this regard, Scenarios $C$ and D would even appear more favorable than what would potentially happen with the permitting for CTR's Hell's Kitchen project.

Table 10. Different cost data based on CEQA/NEPA review timelines.

\begin{tabular}{|c|c|c|c|c|}
\hline Different economic parameters & Scenario A & Scenario B & Scenario C & Scenario D \\
\hline Plant Capacity & $49.9 \mathrm{MW}$ & $49.9 \mathrm{MW}$ & 49.9 MW & $49.9 \mathrm{MW}$ \\
\hline Plant Completion year & 2016 & 2018 & 2019 & 2023 \\
\hline Cumulative land rental until plant completion & $\$ 760,974$ & $\$ 1,001,998$ & $\$ 890,834$ & $\$ 1,341,701$ \\
\hline Exploration CUP cost & $\$ 6,092$ & $\$ 6,092$ & $\$ 6,092$ & $\$ 6,092$ \\
\hline Exploration cost & $\$ 5,820,000$ & $\$ 5,940,000$ & $\$ 6,060,000$ & $\$ 6,240,000$ \\
\hline Utilization CUP cost & $\$ 721,716$ & $\$ 729,006$ & $\$ 743,586$ & $\$ 765,456$ \\
\hline Well Field, Plant \& Transmission & $\$ 423,561,834$ & $\$ 443,925,383$ & $\$ 456,143,513$ & $\$ 476,507,063$ \\
\hline Total cost at completion of project & $\$ 430,870,616$ & $\$ 451,602,480$ & $\$ 463,844,025$ & $\$ 484,860,313$ \\
\hline sLCOE (\$/MWh) & $\$ 103$ & $\$ 107$ & $\$ 110$ & $\$ 114$ \\
\hline Missed Revenue & $\$ 0$ & $\$ 64,287,827$ & $\$ 96,538,835$ & $\$ 227,011,607$ \\
\hline
\end{tabular}

Table 10 presents the summary of different itemized costs, total project costs, sLCOE, and missed revenue (because of the delayed completion of the project in Scenarios B through D). In Scenario A, the permitting process is quicker. The project site is in an area with no significant environmental issue. All responsible agencies concurred with the CEQA analysis and mitigation measures of the Lead Agency (ICPDS). The project is completed within six years from the beginning of the project. The calculated sLCOE is similar to value obtained from Hudson Ranch - I (Figure 16). It is important to note that this hypothetical project that went through expedited permitting and development activities (similar to that of Hudson Ranch - I), and it took six years to complete the project. Even with this faster timeline, it would be difficult to add any new geothermal power to California Public Utilities Commission (CPUC) by 2026 as demanded in the recent Procurement Order (CPUC, 2021) to include at least 1,000 MW from clean firm resources such as geothermal. Developers and some regulators (e.g., CalGEM staff) emphasized the importance of fast-tracking the geothermal permitting processes either by streamlining the review processes to an agency or by exemption (e.g., CEQA exemption) to have significant 
geothermal contribution towards meeting the target of California's renewable energy portfolio by 2030 and beyond.

With increasing environmental sensitivities and complexities in CEQA/NEPA review process, the permitting timeline becomes longer with Scenarios $B$ through $D$ and pushes the project completion dates further into the future. With this, the SLCOE values become higher for the produced electricity. Compared to Scenario $A$, the project completion time is longer than two, three, and seven years in Scenarios B, C, and D, respectively. The SLCOE values with Scenarios B, C, and D are 4 to $11 \%$ higher than the sLCOE with Scenario A. However, the biggest economic impact occurs on the delayed revenue generation. Compared to Scenario A, developers would lose about \$64 million, \$96 million, and \$227 million in Scenarios B, C, and D by the time developers complete the project in the respective scenarios. During our interview with CTR's staff, they categorized this lost revenue generation as one of the biggest economic impacts that could kill the project, keeping it from being successful.

\section{Conclusions}

Development of geothermal resource requires multi-layered regulatory permitting by local, state, and federal agencies. In this study, we collected permit timelines and associated cost data for several existing geothermal power plants and some geothermal projects, which are currently undergoing permitting process for exploration and development activities in California, Nevada, and Utah. The collected data indicate that permitting processes can take a few months to several years with cost ranging from a small amount (e.g., Hudson Ranch - I) to high enough to prematurely end the project.

The assembled data and information from interviews with stakeholders were used to conduct a quantitative evaluation of economic impacts from the permitting cost and timeline on the cost of geothermal electricity. We calculated SLCOE values for three existing power plants and a geothermal project that completed all permitting processes yet did not build the power plant. It is important to note that these four projects completed the permitting process without significant delays. Hence, the variation in computed SLCOE values of these projects primarily depended upon capital costs. However, our analysis confirms that with increasing complexities in permitting processes, the expanded permitting timelines can more than double the project completion timelines with a greater financial impact on the future economic returns.

To evaluate the role of various environmental management and permit review processes on LCOE, we considered a hypothetical geothermal project in the Salton Sea KGRA. This project could be subject to any one of the four CEQA/NEPA review scenarios with increasing biological and environmental issues and involvement of local, state, and federal agencies with overlapping jurisdictions. Although the project is a hypothetical, the scenarios considered largely mimic the CEQA/NEPA review processes that either occurred during permitting processes of prior projects or represent the ongoing permitting processes of some current projects. In these scenarios, the fastest timeline would have the project completed in 6 years. In contrast to this, the project that would go through the longest permitting timeline would require 13 years to complete it. The sLCOE values with longer timelines compared to the sLCOE value with the fastest timeline range from 4 to $11 \%$ higher. A more prominent adverse economic impact from the increasing permitting timelines is illustrated by the potential loss of revenue-between $\$ 64$ and $\$ 227$ million - that the developers could have otherwise generated if the project were completed 
sooner. These results demonstrate that inefficient and protracted permitting processes can, in some cases, determine the success of a geothermal project.

\section{Acknowledgements}

The Idaho National Laboratory is operated by Battelle Energy Alliance, LLC, for DOE's Office of Nuclear Energy. This work was supported by the U.S. Department of Energy, Office of Energy Efficiency and Renewable Energy (EERE), Office of Technology Development, Geothermal Technologies Office (GTO) under DE-AC07-05ID14517 with INL. Regular discussion with Greg Mines was fruitful in developing our TEA approach. Stakeholder outreach efforts were coordinated with Aaron Levine (National Renewable Energy Laboratory) and Dave Goodman (Pacific Northwest National Laboratory). We would like to thank representatives of several regulatory agencies and producers for providing valuable information and sharing their experience. Finally, we appreciate the guidance and feedbacks from GTO Staff, including Sean Porse, Jeff Winick, Jennifer Livermore, and Andy Adams.

\section{References}

Bertani, R., 2016. Geothermal power generation in the world 2010-2014 update report. Geothermics, 60, pp.31-43.

CPUC, 2021. Decision Requiring Procurement to Address Mid-Term Reliability (2023-2026). Decision 2106-035 June 24, 2021, California Public Utilities Commission, 2021, p. 101.

EIA, 2020. Capacity Factors for Utility Scale Generators Primarily Using Non-Fossil Fuels. US Energy Information Administration. Retrieved from https://www.eia.gov/electricity/monthly/epm_table_grapher.php?t=epmt_6_07_b.

Imperial County, 1981. Final Salton Sea Anomaly Master Environmental Impact Report, and Magma Power Plant \# 3 (49 MW) Environmental Impact Report. Imperial County, Volume I and II, p. 978.

Imperial County, 1982. Imperial County geothermal development. Summary report, 1979-1982. Imperial County Report, $28 \mathrm{p}$.

ICPDS, 2015. Renewable energy and transmission element, County of Imperial General Plan. Imperial County Planning and Development Services Department, Imperial County, p. 77.

IID, 2020. Imperial Irrigation District, Energy Consumers Advisory Committee Meeting Minutes on January 6, 2020. Imperial Irrigation District, p. 7.

Levine, A., Young, K.R., and Witherbee, K., 2013. Coordinating Permit Offices and the Development of Utility-Scale Geothermal Energy. GRC Transactions, Vol.37, 2013.

Levine, A. and Young, K. R., 2016. Geothermal Resource Portfolio Optimization and Reporting Tool Protocol: Socio-Economic Assessment Tool, Vol. IV, National Renewable Energy Laboratory, Golden, $\mathrm{CO}$.

Levine, A. and Young, K.R., 2017a. Crossing the Barriers: An Analysis of Land Access Barriers to Geothermal Development and Potential Improvement Scenarios. GRC Transactions, 41. 
Levine, A. and Young, K.R., 2017b. Crossing the Barriers: An Analysis of Permitting Barriers to Geothermal Development and Potential Improvement Scenarios. GRC Transactions, 41.

Loewen, J., 2020. LCOE is an undiscounted metric that inaccurately disfavors renewable energy resources, The Electricity Journal, 33, 106769.

GeoRePORT, 2014. Geothermal Resource Reporting. https://openei.org/wiki/GeoRePORT/About\#top.

Mines, G., 2008. Geothermal Electricity Technologies Evaluation model DOE tool for assessing impact of research on cost of power. PROCEEDINGS, Thirty-Third Workshop on Geothermal Reservoir Engineering, Stanford University, Stanford, California, January 28-30, 2008 SGP-TR-185.

Mines, G.L, 2016. GETEM User Manual. Idaho National Laboratory, INL/EXT-16-38751, p. 194.

Neupane G., Adhikari, B., and Wiggins, A., 2022. Assessment of Economic Impact of Permitting Timelines on Produced Geothermal Power in Imperial County, California. PROCEEDINGS, 47th Workshop on Geothermal Reservoir Engineering Stanford University, Stanford, California, February 7-9, 2022 SGP-TR-223.

Richard, C., 2012. Developmental Barriers vs. Policy Incentives in Geothermal Power. GRC Transactions, $36,115-120$.

Rickard, W., Bailey, A., Pahler, M. and Cory, S., 2014, February. Kymera ${ }^{\mathrm{TM}}$ hybrid bit technology reduces drilling cost. In Proceedings of the Thirty-Ninth Workshop on Geothermal Reservoir Engineering, Stanford University, Stanford, California.

U.S. Department of Energy, 2019. GeoVision: Harnessing the Heat Beneath our Feet. DOE/EE-1306. U.S. Department of Energy, Washington, D.C., p. 218.

USGAO, 2013. Renewable Energy: Agencies have taken steps aimed at improving the permitting process for development on federal lands. United States Government Accountability Office, p. 56.

Williams, C.F., Reed, M.J., Mariner, R.H., DeAngelo, J., and Galanis, S.P. Jr., 2008. Assessment of moderate- and high-temperature geothermal resources of the United States. US Department of the Interior, US Geological Survey, Fact Sheet 2008-3082.

Young, K.R., Witherbee, K., Levine, A., Keller, A., Balu, J. and Bennett, M., 2014. Geothermal Permitting and NEPA Timelines. GRC Transactions, 38, 893-903.

Young, K.R. and Levine, A., 2018. Using GeoRePORT to report socio-economic potential for geothermal development. Geothermics, 74,163-171.

Young, K., Levine, A., Cook, J., Heimiller, D., Ho, J., 2019. Barriers: An Analysis of Non-Technical Barriers to Geothermal Deployment and Potential Improvement Scenarios. National Renewable Energy Laboratory, Golden, CO, Technical Report NREL/PR-6A20-71641, p. 126. 


\section{Appendices}

\section{Appendix A. Supplementary Tables}

Table A1. List of stakeholders interviewed for the project.

\begin{tabular}{|c|c|c|}
\hline Type of Agencies & Agency & Date/Interviewees \\
\hline \multirow[t]{2}{*}{$\begin{array}{l}\text { Local (Imperial County, } \\
\text { CA) }\end{array}$} & IC Planning and Development Services & $\begin{array}{l}\text { March 30, } 2021 \\
\text { Jim Minnick (Director) }\end{array}$ \\
\hline & Imperial Irrigation District & $\begin{array}{l}\text { March 18, } 2021 \\
\text { Alex Cardenas (Director) and } \\
\text { Enrique Martinez (General Manager) }\end{array}$ \\
\hline \multirow[t]{3}{*}{ State (California) } & CalGEM & $\begin{array}{l}\text { March 19, } 2021 \\
\text { Charlene Wardlow (Geothermal Program } \\
\text { Manager) }\end{array}$ \\
\hline & California Dept. of Fish and Wildlife & $\begin{array}{l}\text { April 1, } 2021 \\
\text { Scott Wilson (Program Manager) }\end{array}$ \\
\hline & California Energy Commission & $\begin{array}{l}\text { July 28, } 2021 \\
\text { Eric Knight (Manager) }\end{array}$ \\
\hline \multirow[t]{4}{*}{ Federal (for California) } & Bureau of Land Management (BLM) & $\begin{array}{l}\text { July 15, } 2021 \\
\text { Dan Munger (Geothermal Program Lead) } \\
\text { Ryan Chatterton (Field Manager) } \\
\text { Carrie Sahagun (Asst. Field Manager) }\end{array}$ \\
\hline & U.S. Fish and Wildlife Service & $\begin{array}{l}\text { April 15, } 2021 \\
\text { Colleen Draguesku (Biologist) } \\
\text { Mark Elvin (Regional Coordinator) }\end{array}$ \\
\hline & U.S. Bureau of Reclamation & $\begin{array}{l}\text { April 16, } 2021 \\
\text { Genevieve Johnson (Program Manager) }\end{array}$ \\
\hline & U.S. Army Corp of Engineers & $\begin{array}{l}\text { May 25, } 2021 \\
\text { Kyle Dahl (Chief, San Diego \& Imperial } \\
\text { Counties Section, Regulatory Division ) }\end{array}$ \\
\hline Federal (for Nevada) & Bureau of Land Management (BLM) & $\begin{array}{l}\text { July 7, } 2021 \\
\text { Frederick (Cooper) Kaminer (Geologist) } \\
\text { Alex Jensen (Program Lead) } \\
\text { David Schroeder (District Office Lead) }\end{array}$ \\
\hline \multirow[t]{4}{*}{ Operators/Developers } & EnergySource & $\begin{array}{l}\text { April 6, } 2021 \\
\text { Jurg Heuberger (Permitting Specialist; } \\
\text { former ICPDS Director) }\end{array}$ \\
\hline & Controlled Thermal Resources & $\begin{array}{l}\text { May 5, } 2021 \\
\text { Rod Colwell (CEO) } \\
\text { Jim Turner (COO) } \\
\text { Jason Czapla (Principal Engineer) }\end{array}$ \\
\hline & CalEnergy & $\begin{array}{l}\text { June 10, } 2021 \\
\text { Jonathan Weisgall (VP, Legislative \& } \\
\text { Regulatory Affairs) }\end{array}$ \\
\hline & Layman Energy Associates & $\begin{array}{l}\text { May 3, } 2021 \\
\text { Erik Layman (President) }\end{array}$ \\
\hline
\end{tabular}


Table A2. List of documents reviewed to obtain timelines data.

\begin{tabular}{|c|c|}
\hline Agencies & Document types \\
\hline \multicolumn{2}{|c|}{ Federal Agencies } \\
\hline \multirow[t]{12}{*}{ BLM } & Lease application and approval documents \\
\hline & Applications \\
\hline & Notice of Intent (NOI) documents \\
\hline & Casual Use (CU) documents \\
\hline & Determination of NEPA Adequacy (DNA) documents \\
\hline & Categorical Exclusion (CX) documents \\
\hline & Notice of Preparation (NOP) documents \\
\hline & Notice of Completion (NOC) documents \\
\hline & Environmental Assessment (EA) reports \\
\hline & Findings of No Significant Impact (FONSI) documents \\
\hline & Environmental Impact Statement reports \\
\hline & Decision Records \\
\hline USFWS & Comments provided to Lead Agency (embedded in the EA, EIS, or EIR) \\
\hline USEPA & Comments provided to Lead Agency (embedded in the EA, EIS, or EIR) \\
\hline DOD/Air Force & Comments provided to Lead Agency (embedded in the EA, EIS, or EIR) \\
\hline \multicolumn{2}{|r|}{ State Agencies - California } \\
\hline \multirow[t]{6}{*}{ CEC } & Application for Certification document \\
\hline & Preliminary Staff Assessment document \\
\hline & Final Staff Assessment document \\
\hline & Decision records \\
\hline & Certification record \\
\hline & California Clearing House records \\
\hline \multirow[t]{3}{*}{ CalGEM } & Comments provided to Lead Agency (embedded in the EA, EIS, or EIR) \\
\hline & Well drilling permit applications and decisions \\
\hline & Well records including history, summary, and logs \\
\hline CDWR & Comments provided to Lead Agency (embedded in the EA, EIS, or EIR) \\
\hline CDFW & Comments provided to Lead Agency (embedded in the EA, EIS, or EIR) \\
\hline CDOT & Comments provided to Lead Agency (embedded in the EA, EIS, or EIR) \\
\hline CRBC & Comments provided to Lead Agency (embedded in the EA, EIS, or EIR) \\
\hline NAHC & Comments provided to Lead Agency (embedded in the EA, EIS, or EIR) \\
\hline CDTSC & Comments provided to Lead Agency (embedded in the EA, EIS, or EIR) \\
\hline \multicolumn{2}{|c|}{ Imperial County Agencies } \\
\hline \multirow[t]{8}{*}{ ICPDS } & Notice of Intent documents \\
\hline & Notice of Preparation documents \\
\hline & Notice of Declaration documents \\
\hline & Initial Study reports \\
\hline & Negative Declaration documents \\
\hline & Mitigated Negative Declaration documents \\
\hline & Environmental Impact Report \\
\hline & Final Environmental Impact Report \\
\hline
\end{tabular}




\begin{tabular}{|l|l|}
\hline $\begin{array}{l}\text { The Nevada } \\
\text { Division of } \\
\text { Minerals }\end{array}$ & Well drilling permits and well logs \\
\hline Churchill County Agencies \\
\hline $\begin{array}{l}\text { Public Works, } \\
\text { Planning \& } \\
\begin{array}{l}\text { Zoning } \\
\text { Department }\end{array}\end{array}$ \\
\hline \begin{tabular}{l} 
State Agencies- Utah \\
\hline $\begin{array}{l}\text { UT Governor's } \\
\text { office }\end{array}$
\end{tabular} \\
\hline $\begin{array}{l}\text { Utah State } \\
\text { Historic } \\
\text { Preservation } \\
\text { Office }\end{array}$ \\
\hline Beaver and Millard Counties \\
\hline $\begin{array}{l}\text { County } \\
\text { commissions }\end{array}$ & Comments on EA/EIS \\
\hline
\end{tabular}


Table A3. List of commenters on Draft EA for Dixie Meadow Utilization (DOI-BLM-NV-C010-2016-0014EA).

\begin{tabular}{|c|c|}
\hline $\begin{array}{l}\text { Commenters on Draft EA (Review Period: } \\
5 / 9 / 2017-6 / 30 / 2017 \text { ) }\end{array}$ & $\begin{array}{l}\text { Commenters on modified Draft EA (Review } \\
\text { Period: } 1 / 13 / 2021-2 / 12 / 2021 \text { ) }\end{array}$ \\
\hline $\begin{array}{l}\text { Federal: } \\
\qquad \text { US Fish and Wildlife }\end{array}$ & $\begin{array}{l}\text { Federal: } \\
\text { - US Fish and Wildlife } \\
\text { - Naval Air Station Fallon }\end{array}$ \\
\hline $\begin{array}{l}\text { Nevada Agencies: } \\
\text { - } \text { Department of Environmental } \\
\text { - } \quad \text { Division of Water Resources } \\
\text { - } \\
\text { - } \\
\text { - Sevada Department of Wildlife } \\
\text { - State Land Use Planning Agency }\end{array}$ & $\begin{array}{l}\text { Nevada Agencies: } \\
\text { - Division of Water Resources } \\
\text { - Nevada Department of Wildlife } \\
\text { - } \text { Department of Transportation }\end{array}$ \\
\hline Local Agencies: & $\begin{array}{l}\text { Local Agencies: } \\
\qquad \quad \text { Churchill County, NV }\end{array}$ \\
\hline $\begin{array}{l}\text { Tribes: } \\
\text { - Fallon Paiute-Shoshone Tribe }\end{array}$ & $\begin{array}{l}\text { Tribes: } \\
\text { - Fallon Paiute-Shoshone Tribe }\end{array}$ \\
\hline $\begin{array}{l}\text { Environmental Groups: } \\
\text { - Sierra Club } \\
\text { - } \text { Basin and Range Watch } \\
\text { - Center for Biological Diversity (CBD) } \\
\text { - Defenders of Wildlife } \\
\text { - WildLands Defense }\end{array}$ & $\begin{array}{l}\text { Environmental Groups: } \\
\text { - Center for Biological Diversity }\end{array}$ \\
\hline $\begin{array}{l}\text { Private citizens: } \\
\text { - } \text { Rob Mrowka, CBD } \\
\text { - } \text { Michelle Gordon, University of Nevada } \\
\text { - } \text { CR Tracy, University of Nevada } \\
\text { Eric T Simandle, Paul Smith's College }\end{array}$ & \\
\hline
\end{tabular}




\section{Appendix B. Supplementary Figures}

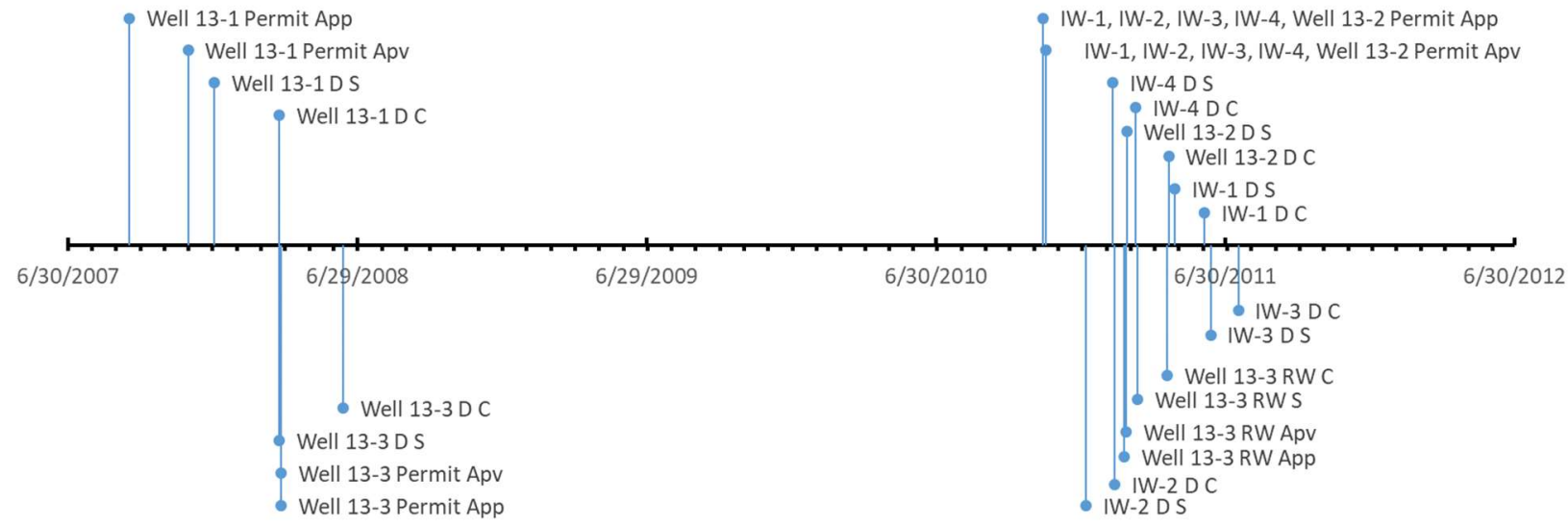

Figure B1. Timelines of application (App), approval (Apv), drilling start (DS), and drilling completion (DC) of wells for Hudson Ranch - I.

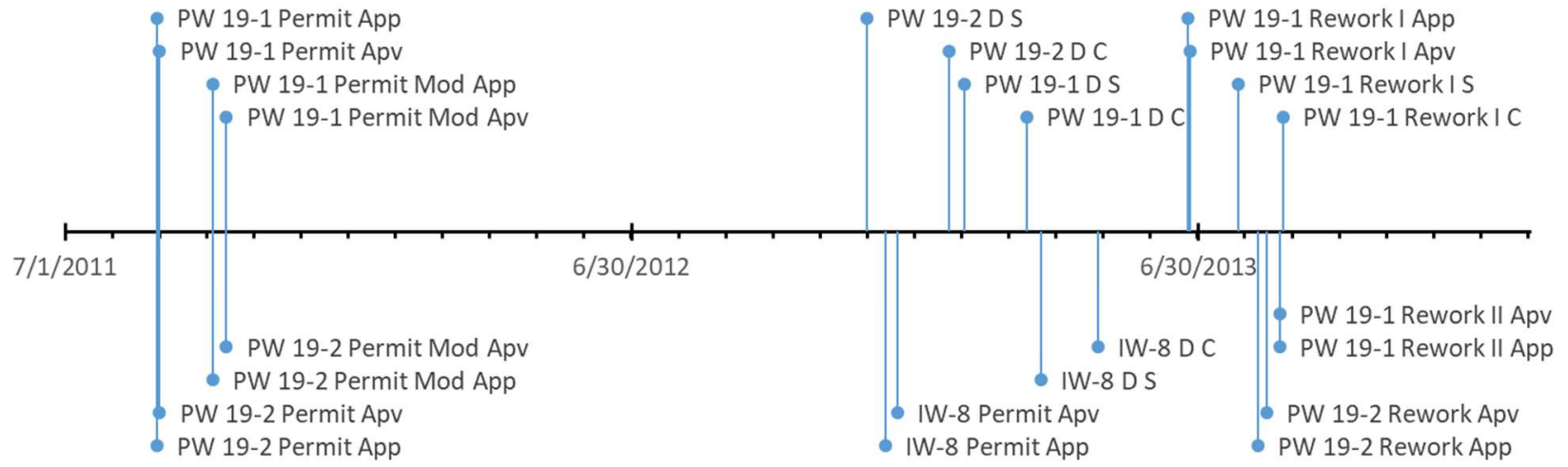

Figure B2. Timelines of application (App), approval (Apv), drilling start (DS), and drilling completion (DC) of wells for Hudson Ranch - II. 


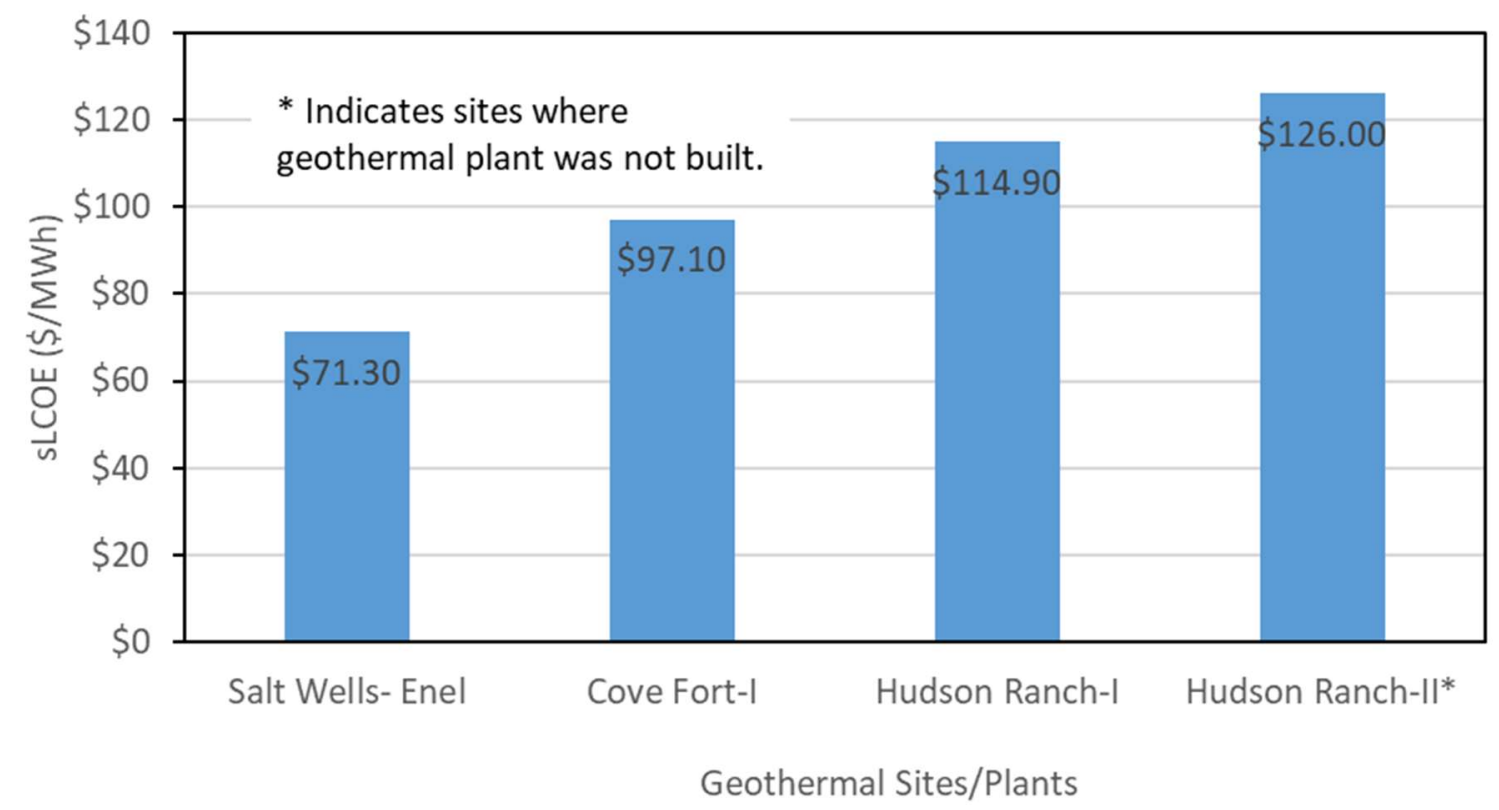

Figure B3. LCOE at different sites using GETEM. 